July 6, 1999

Federal Energy Technology Center

AAD Document Control

U.S. Department of Energy

PO Box 10940, MS 921-143

Pittsburgh, PA 15236-0940

Dear AAD Document Control:

Subject: EERC Final Report; Cooperative Agreement No. DE-FC21-93MC30098--65; Task 63-Field Validation of the Ontario Hydro Mercury Speciation Sampling Method; Fund 4426

Please find enclosed one copy of the final topical report for the subject project. A draft copy was submitted to the performance monitor on March 17, 1999. No changes were required; therefore, we are enclosing the final report with the Patent Clearance Form and the electronic copy on diskette.

If you have any questions, please feel free to contact me by phone at (701) 777-5124, by fax at (701) 777-5181, or by e-mail at slandis@eerc.und.nodak.edu.

Sincerely,

Sheryl E. Landis

Manager, Contracts and Intellectual Property

Business and Operations

$\mathrm{SEL} / \mathrm{mjj}$

Enclosure 


\section{FIELD VALIDATION OF THE ONTARIO HYDRO MERCURY SPECIATION SAMPLING METHOD AT SITE E-29}

EERC Final Report

Prepared for:

Federal Energy Technology Center

AAD Document Control

U.S. Department of Energy

PO Box 10940, MS 921-143

Pittsburgh, PA 15236-0940

Prepared by:

Dennis L. Laudal

Energy \& Environmental Research Center

University of North Dakota

PO Box 9018

Grand Forks, ND 58202-9018

99-EERC-07-02

July 1999 


\section{TABLE OF CONTENTS}

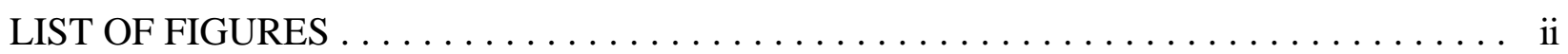

LIST OF TABLES $\ldots \ldots \ldots \ldots \ldots \ldots \ldots \ldots \ldots \ldots \ldots \ldots \ldots \ldots$ ii

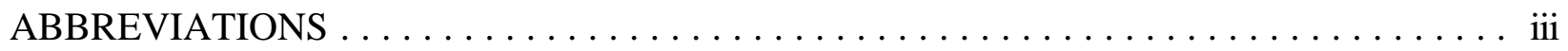

1.0 INTRODUCTION AND BACKGROUND $\ldots \ldots \ldots \ldots \ldots \ldots \ldots \ldots \ldots \ldots \ldots$

2.0 TEST PROGRAM OBJECTIVES $\ldots \ldots \ldots \ldots \ldots \ldots \ldots \ldots \ldots \ldots \ldots$

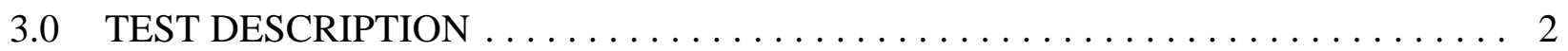

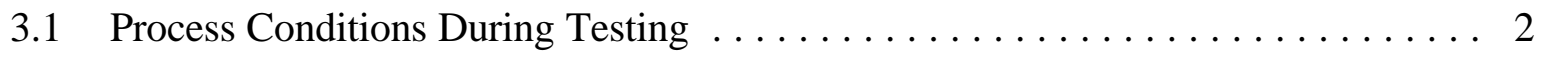

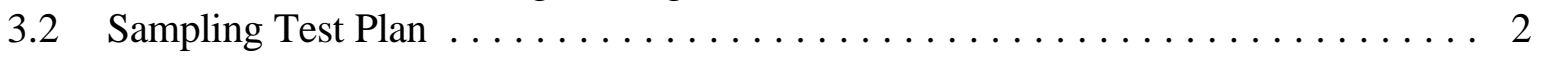

4.0 FLUE GAS SAMPLING AND ANALYTICAL METHODS AND QUALITY ASSURANCE/QUALITY CONTROL $\ldots \ldots \ldots \ldots \ldots \ldots \ldots \ldots \ldots \ldots \ldots$

4.1 Ontario Hydro Mercury Speciation Method $\ldots \ldots \ldots \ldots \ldots \ldots \ldots \ldots \ldots$

$4.2 \quad$ Semtech $\mathrm{Hg} 2000$ Analyzer . . . . . . . . . . . . . . . . . . . . . 9

4.3 Oxygen Concentration, Flue Gas Velocity, and Moisture ............. 9

4.4 Quality Assurance/Quality Control (QA/QC) $\ldots \ldots \ldots \ldots \ldots \ldots \ldots \ldots \ldots$

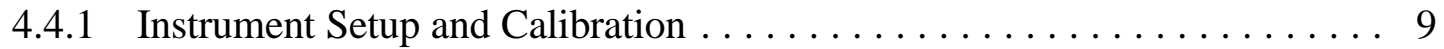

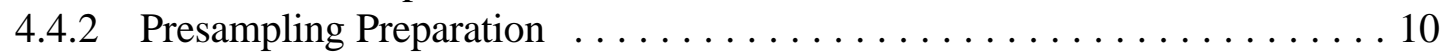

4.4.3 Glassware and Plasticware Cleaning and Storage $\ldots \ldots \ldots \ldots \ldots \ldots$

4.4.4 Analytical Reagents .............................. 10

4.4 .5 Blanks . . . . . . . . . . . . . . . . . . . . . . . . . 11

4.4.6 Spiked Samples ................................ 11

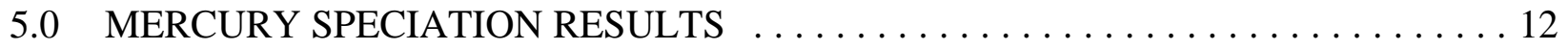

5.1 Ontario Hydro Mercury Speciation Validation Results ................ 12

5.2 Statistical Error/Variability Associated with the Ontario Hydro Method ...... 15

5.3 Mercury Removal Across the FGD System . . . . . . . . . . . . . . . 16

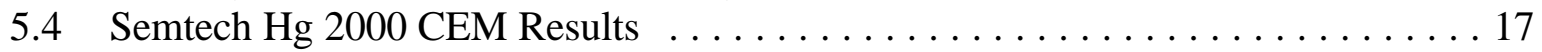

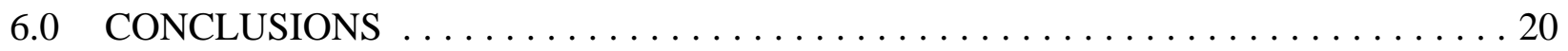

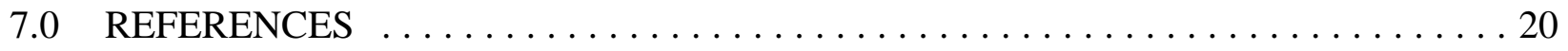

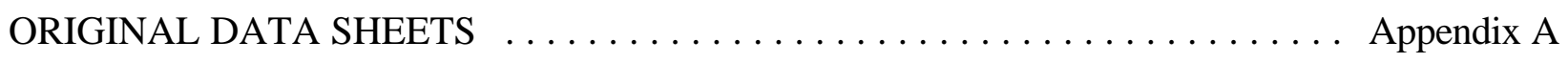




\section{LIST OF FIGURES}

$1 \quad \mathrm{SO}_{2}$ concentration at the inlet and outlet of the FGD system $\ldots \ldots \ldots \ldots$

2 Schematic of the Ontario Hydro mercury speciation method sampling train . . . . . . 7

3 Teardown schematic of the Ontario Hydro mercury speciation method sampling train . . 8

4 The change in vapor-phase speciated mercury across the FGD system $\ldots \ldots \ldots \ldots$

5 Direct comparison between Semtech mercury CEM and Ontario Hydro

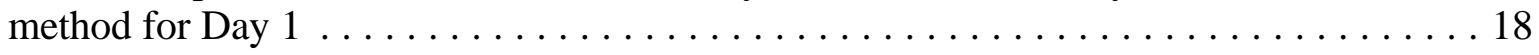

6 Direct comparison between Semtech mercury CEM and Ontario Hydro

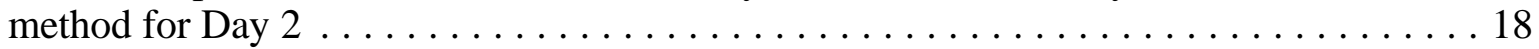

7 Direct comparison between Semtech mercury CEM and Ontario Hydro

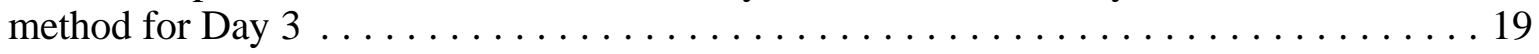

8 Direct comparison between Semtech mercury CEM and Ontario Hydro

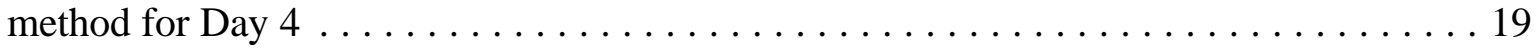

\section{LIST OF TABLES}

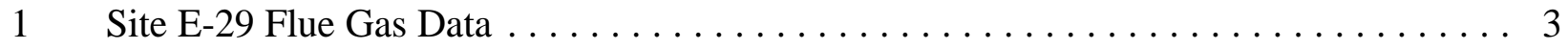

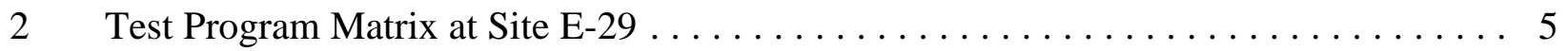

3 Average Excess Oxygen and Moisture Content at Mercury Speciation Sampling Points . 6

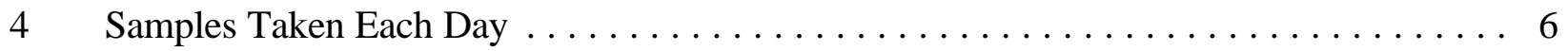

5 Results of Mercury Speciation Field Blanks $\ldots \ldots \ldots \ldots \ldots \ldots \ldots \ldots \ldots \ldots \ldots$

6 Results of Mercury Speciation Field Spikes $\ldots \ldots \ldots \ldots \ldots \ldots \ldots \ldots \ldots$

7 Mercury Speciation Quadtrain Sampling Results Using the Ontario Hydro Method . . . . 13

8 Statistical Results for Precision for the Quadtrain Data from the Ontario Hydro Method . 13

9 Statistical Results for Bias for the Quadtrain Data from the Ontario Hydro Method . . . 14

10 Mercury Speciation Results Across the FGD System $\ldots \ldots \ldots \ldots \ldots \ldots \ldots$ 


\section{ABBREVIATIONS}

ASTM American Society for Testing and Materials

${ }^{\circ} \mathrm{C}$ degrees Celsius

CAAAs Clean Air Act Amendments

CEM continuous emission monitor

$\mathrm{Cl}_{2} \quad$ chlorine gas

CVAA cold-vapor atomic absorption

DOE U.S. Department of Energy

EERC Energy \& Environmental Research Center

EPA U.S. Environmental Protection Agency

ESP electrostatic precipitator

${ }^{\circ} \mathrm{F}$ degrees Fahrenheit

FGD flue gas desulfurization

$\mathrm{H}_{2} \mathrm{O}_{2} \quad$ hydrogen peroxide

$\mathrm{H}_{2} \mathrm{SO}_{4} \quad$ sulfuric acid

$\mathrm{HCl}$ hydrogen chloride

HF hydrofluoric acid

$\mathrm{Hg}$ mercury

$\mathrm{Hg}^{0} \quad$ elemental mercury

$\mathrm{Hg}^{2+} \quad$ oxidized mercury

$\mathrm{HNO}_{3} \quad$ nitric acid

$\mathrm{hr}$ hour

ICR information collection request

$\mathrm{KCl}$ potassium chloride

L liter

lb pound

min minute

MW megawatt

NIST National Institute of Standards and Technology

nm nanometer

$\mathrm{Nm}^{3} \quad$ normal cubic meter $\left(20^{\circ} \mathrm{C}\right.$ and 1 atmosphere $)$

$\mathrm{O}_{2} \quad$ oxygen

$\mathrm{ppb} \quad$ parts per billion

QA quality assurance

QC quality control

scf standard cubic feet

scfm standard cubic feet per minute

$\mathrm{SO}_{2} \quad$ sulfur dioxide

$\mathrm{SO}_{3} \quad$ sulfur trioxide

Std. Dev. standard deviation

$\mu \mathrm{g}$ micrograms

$\% \mathrm{~V} / \mathrm{v} \quad$ percentage by volume

$\% \mathrm{w} / \mathrm{v} \quad$ percentage by weight 


\section{FIELD VALIDATION OF THE ONTARIO HYDRO MERCURY SPECIATION SAMPLING METHOD AT SITE E-29}

\subsection{INTRODUCTION AND BACKGROUND}

The 1990 Clean Air Act Amendments (CAAAs) required the U.S. Environmental Protection Agency (EPA) to determine whether the presence of mercury in the stack emissions from fossil fuel-fired electric utility power plants poses an unacceptable public health risk. EPA's conclusions and recommendations were presented in the Mercury Study Report to Congress (1) and the Utility Air Toxics Report to Congress (1). The first report addressed both the human health and environmental effects of anthropogenic mercury emissions, while the second addressed the risk to public health posed by the emission of mercury and other hazardous air pollutants from steam-electric generating units. Given the current state of the art, these reports did not state that mercury controls on coal-fired electric power stations would be required. However, the reports did indicate that EPA views mercury as a potential threat to human health. EPA indicated that additional research and information were necessary before any definitive statement could be made. This has led EPA to issue an information collection request (ICR). The mercury- sampling method proposed for the ICR is the Ontario Hydro mercury speciation method. This method was extensively tested at the Energy \& Environmental Research Center (EERC) in a program funded by EPRI and the U.S. Department of Energy (DOE). However, because the testing had primarily been done at the pilot-scale level, it was decided to more formally evaluate the method in the field.

The more formal validation of the Ontario Hydro method was done at a midwestern power plant burning a bituminous coal. For purposes of this report, the plant has been labeled Site E-29. The testing was done as part of a program entitled "Characterization and Modeling of the Forms of Mercury from Coal-Fired Power Plants." This program, which was initiated in October 1997, was to develop models to predict mercury speciation in flue gas from coal-fired systems based on relatively simple inputs such as coal analyses, plant configuration, and coal type. This program is sponsored by EPRI and DOE, and the work is being done by Radian International and the EERC. Site E-29 was chosen for this validation test because the high sulfur and chloride content of the coal being burned at this facility would provide a challenge to the method. In addition, pilot-scale tests done with the coal burned indicated that the concentration of elemental mercury $\left(\mathrm{Hg}^{0}\right)$ and oxidized mercury $\left(\mathrm{Hg}^{2+}\right)$ was well above the comfort level of detection for the method $\left(>0.5 \mu \mathrm{g} / \mathrm{Nm}^{3}\right)$. 


\subsection{TEST PROGRAM OBJECTIVES}

The two objectives of the test program are as follows:

- To more formally validate the Ontario Hydro mercury speciation method in the field using a modified EPA Method 301 procedure.

- To collect data at the power plant for mercury speciation modeling activities. In addition, it is expected that the collected data can be used to satisfy the requirements of the ICR.

\subsection{TEST DESCRIPTION}

Site E-29 is located in the Midwest and has a capacity of 1330 megawatts (MW). Site E-29 is designed to burn up to 3.7 million tons of coal per year. The plant has two electrostatic precipitators (ESPs) to control particulate matter and a limestone wet flue gas desulfurization system (FGD) to control $\mathrm{SO}_{2}$ emissions. As stated earlier, the coal burned at the plant is a bituminous coal that is brought to the plant by rail where it is stockpiled prior to crushing and pulverization. The pulverized coal is fed to the boilers pneumatically and injected into the furnace through the burners.

\subsection{Process Conditions During Testing}

Table 1 summarizes the average load and gas emissions during the mercury speciation test program. The FGD system for this plant was very efficient, $>90 \%$. Although the load data are consistent from day to day, there is variability in the inlet $\mathrm{SO}_{2}$ data. This becomes more apparent when the hourly $\mathrm{SO}_{2}$ data are plotted as a function of time, as shown in Figure 1. This indicates variability in the coal being fired in the boiler.

\subsection{Sampling Test Plan}

The inlet sampling location at the FGD was also the sampling location for the ESP outlet. Because the unit has two ESPs, the flue gas must be split into two streams, but after passing through the ESPs, the flue gas then is recombined into a single duct. The sample port for the ESP 
TABLE 1

Site E-29 Flue Gas Data

\begin{tabular}{|c|c|c|c|c|c|c|}
\hline Date & $\begin{array}{c}\text { Gross } \\
\text { Load, } \\
\text { MW }\end{array}$ & $\begin{array}{c}\mathrm{NO}_{\mathrm{x}}, \\
\operatorname{ppm}(\mathbf{v})\end{array}$ & $\begin{array}{c}\mathrm{CO}_{2} \\
\%\end{array}$ & $\begin{array}{c}\mathrm{SO}_{2} \text { at the } \\
\text { FGD Inlet, } \\
\operatorname{ppm(v)}\end{array}$ & $\begin{array}{c}\mathrm{SO}_{2} \text { at the } \\
\text { FGD Inlet, } \\
\operatorname{ppm}(\mathrm{v})\end{array}$ & $\begin{array}{c}\mathrm{SO}_{2} \\
\text { Removal } \\
\text { Across FGD, } \\
\%\end{array}$ \\
\hline $10-15-98$ & 1324 & 211 & 11.8 & 2145 & 133 & 93.8 \\
\hline $10-16-98$ & 1313 & 207 & 11.9 & 2736 & 184 & 93.3 \\
\hline $10-17-98$ & 1313 & 195 & 11.9 & 2831 & 161 & 94.3 \\
\hline $10-18-98$ & 1298 & 198 & 11.8 & 2653 & 142 & 94.6 \\
\hline
\end{tabular}

outlet/FGD inlet was located after the flue gas streams had recombined but prior to the FGD modules. The sampling activities that were completed at Site E-29 are shown in Table 2.

All the sampling activities were completed by Radian; however, the analysis of the Ontario Hydro impinger samples was done in the field by the EERC using a portable cold-vapor atomic absorption (CVAA) analyzer. The filter samples were taken back to the EERC and analyzed by the EERC's Analytical Research Laboratory. In addition to doing the analyses, the EERC operated a Semtech Hg 2000 mercury continuous emission monitor (CEM) at the stack.

This report will focus on the Ontario Hydro method and CEM results. Radian and the EERC will provide a complete report for all the sampling activities at Site E-29, including other trace elements and chlorides, prior to completion of the "Characterization and Modeling of the Forms of Mercury from Coal-Fired Power Plants" project.

At the FGD inlet, a modified EPA Method 301 test was completed to validate the Ontario Hydro mercury speciation method. The analyte-spiking protocol procedure detailed in EPA Method 301 was used. For this procedure, it is required that six quadtrain replicates be done with half of the impinger trains being spiked with mercury prior to sampling (two sets of impinger trains in each quadtrain). In this way, the precision and bias of the sampling method being tested can be determined. However, because of time and monetary constraints, it was decided that only five replicate quadtrains, along with all of the pilot-scale work that had been done in the past, would provide enough statistical evidence to determine whether the method was valid. This testing resulted in a total of 20 samples being collected at the FGD inlet. 


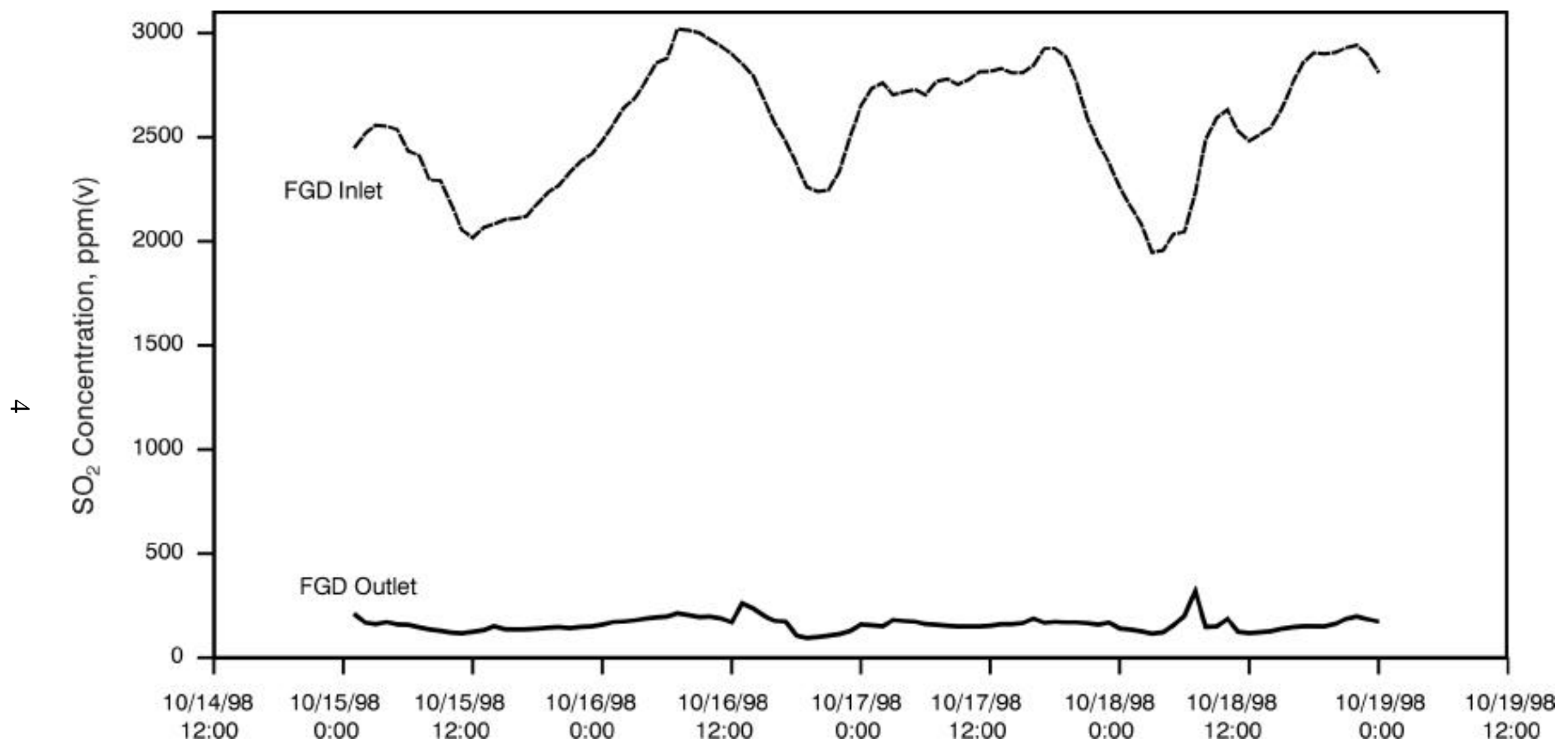

Figure $1 . \mathrm{SO}_{2}$ concentration at the inlet and outlet of the FGD system. 
TABLE 2

Test Program Matrix at Site E-29

\begin{tabular}{|c|c|c|c|c|c|c|}
\hline \multirow[b]{2}{*}{ Process Stream } & \multicolumn{6}{|c|}{ Target Species $^{T}$} \\
\hline & $\mathbf{H g}^{0}$ & $\mathbf{H g}^{2+}$ & $\begin{array}{c}\text { Total } \\
\text { Hg }\end{array}$ & $\begin{array}{c}\text { Chlorides } \\
\text { (CI ) }\end{array}$ & $\mathrm{SO}_{3}$ & $\begin{array}{c}\text { Other } \\
\text { Trace } \\
\text { Elements }\end{array}$ \\
\hline \multicolumn{7}{|l|}{ Flue Gas Sample Streams } \\
\hline ESP Outlet/FGD Inlet & $\mathrm{X}$ & $\mathrm{X}$ & $\mathrm{X}$ & $\mathrm{X}$ & $\mathrm{X}$ & $\mathrm{X}$ \\
\hline Stack & $\mathrm{X}$ & $\mathrm{X}$ & $\mathrm{X}$ & & & $\mathrm{X}$ \\
\hline \multicolumn{7}{|l|}{ Solid Samples } \\
\hline Coal Feeders & & & $\mathrm{X}$ & $\mathrm{X}$ & $\mathrm{X}^{2}$ & $\mathrm{X}$ \\
\hline ESP Hoppers & & & $\mathrm{X}$ & & $\mathrm{X}$ & $X$ \\
\hline Lime & & & $\mathrm{X}$ & & & \\
\hline $\begin{array}{l}\text { For the flue gas streams, merc } \\
\text { method; the other trace eleme } \\
\text { gas was measured using EPA } \\
\text { using the selective condensati }\end{array}$ & dhod. & $\begin{array}{l}\text { peciate } \\
\text { d meas } \\
\text { oth } \mathrm{HCl}\end{array}$ & $\begin{array}{l}\frac{}{\text { total) we }} \\
\text { sing EP } \\
\mathrm{Cl}_{2} \text { ), and }\end{array}$ & $\begin{array}{l}\text { made using } \\
\text { Method 29. T } \\
\mathrm{SO}_{3} \text { concer }\end{array}$ & ation & $\begin{array}{l}\text { Hydro } \\
\text { e in the flue } \\
\text { s measured }\end{array}$ \\
\hline
\end{tabular}

At the stack, four sets of duplicate Ontario Hydro method samples were taken. Simultaneously, duplicate EPA Method 29 samples were taken at both the FGD inlet and stack. The EPA Method 29 samples were done to measure trace elements other than mercury. EPA Method 26A (chlorides) and $\mathrm{SO}_{3}$ samples were taken when the quadtrain samples were being done. The EPA Method 29, EPA Method 26A, and $\mathrm{SO}_{3}$ samples were taken and analyzed by Radian and are unavailable for this report.

The duplicate Ontario Hydro and EPA Method 29 samples were taken using a full traverse procedure. However, because of the nature of quadtrains, traversing was not possible, and these samples were taken at a single point. The average moisture and oxygen content at each sample point is shown in Table 3. The samples taken each day are listed in Table 4. 
TABLE 3

Average Excess Oxygen and Moisture Content at Mercury Speciation Sampling Points

\begin{tabular}{lcc}
\hline Sample Location & $\begin{array}{c}\text { Excess } \mathbf{O}_{2} \\
\text { (on a dry basis), } \%\end{array}$ & $\begin{array}{c}\text { Moisture } \\
\text { Content, } \%\end{array}$ \\
\hline ESP Outlet/FGD Inlet & 7.8 & 8.6 \\
Stack & 9.6 & 14.4 \\
\hline
\end{tabular}

TABLE 4

Samples Taken Each Day

\begin{tabular}{cccccc}
\hline Day & \multicolumn{2}{c}{ ESP Outlet/FGD Inlet ${ }^{\mathbf{1 2}}$} & \multicolumn{2}{c}{ Stack } \\
\cline { 2 - 3 } \cline { 5 - 6 } 1 & Ontario Hydro Method & EPA Method 29 & & Ontario Hydro Method & EPA Method 29 \\
\cline { 2 - 3 } 2 & 1 quadtrain & & & 1 duplicate & 1 duplicate \\
3 & 1 quadtrain & 1 duplicate & & 2 duplicates & 2 duplicates \\
4 & 1 quadtrain & 2 duplicates & & & \\
\hline
\end{tabular}

${ }^{1}$ Three EPA Method 26A samples were also completed for chlorides and selective condensation samples for $\mathrm{SO}_{3}$.

${ }^{2}$ The Semtech $\mathrm{Hg} 2000 \mathrm{CEM}$ was to be used to measure total mercury and $\mathrm{Hg}^{0}$ at the FGD inlet.

\subsection{FLUE GAS SAMPLING AND ANALYTICAL METHODS AND QUALITY ASSURANCE/QUALITY CONTROL}

This section describes the Ontario Hydro mercury speciation method, the Semtech Hg 2000 mercury CEM, and analytical procedures that were used for this test program to determine the mercury speciation.

\subsection{Ontario Hydro Mercury Speciation Method}

The Ontario Hydro method was developed by Keith Curtis and other researchers at Ontario Hydro Technologies in late 1994. Since testing with EPA Method 29 appeared to show that some of the $\mathrm{Hg}^{0}$ was captured in the nitric acid-hydrogen peroxide $\left(\mathrm{HNO}_{3}-\mathrm{H}_{2} \mathrm{O}_{2}\right)$ impingers, an attempt was made to more selectively capture the $\mathrm{Hg}^{2+}$ by substituting three aqueous $1 \mathrm{~N}$ 
potassium chloride $(\mathrm{KCl})$ impinger solutions for one of the $\mathrm{HNO}_{3}-\mathrm{H}_{2} \mathrm{O}_{2}$ solutions. A schematic of the impinger train is shown in Figure 2. The Ontario Hydro method has been extensively tested at the EERC and has been shown to provide accurate mercury speciation data for coal-fired boilers $(2,3)$. The method is currently being evaluated by American Society for Testing and Materials (ASTM) Subcommittee D22.03.01. A complete description of the Ontario Hydro method in the ASTM format is available at http://www.epa.gov/ttn/emc/prelim.html.

All glassware for the sample trains was precleaned using a 4-hr soak in a $10 \% \mathrm{HNO}_{3}$ solution. No impinger glassware was used more than once in the field test. Samples collected using the Ontario Hydro method were recovered into the following fractions:

- Probe ash and particulate filter and ash - Container No. 1

- Probe rinse with $0.1 \mathrm{~N} \mathrm{HNO}_{3}$ solution - Container No. $2 \mathrm{~A}$

- Back half of the filter holder and connecting U-tubes $0.1 \mathrm{~N} \mathrm{HNO}_{3}$ rinses plus the three $\mathrm{KCl}$ impinger solutions and their $0.1 \mathrm{~N} \mathrm{HNO}_{3}$ rinses - Container No. $2 \mathrm{~B}$

- The $\mathrm{HNO}_{3}-\mathrm{H}_{2} \mathrm{O}_{2}$ solution and its $0.1 \mathrm{~N} \mathrm{HNO}_{3}$ rinse and the rinse of the U-tube between the last $\mathrm{KCl}$ impinger and $\mathrm{H}_{2} \mathrm{O}_{2}-$ Container No. 3

- $\mathrm{H}_{2} \mathrm{SO}_{4}-\mathrm{KMnO}_{4}$ impinger and rinses $\left(0.1 \mathrm{~N} \mathrm{HNO}_{3}\right.$ rinses and $8 \mathrm{~N} \mathrm{HCl}$ rinses $)$ and the rinse of the U-tubes rinses - Container No. 4

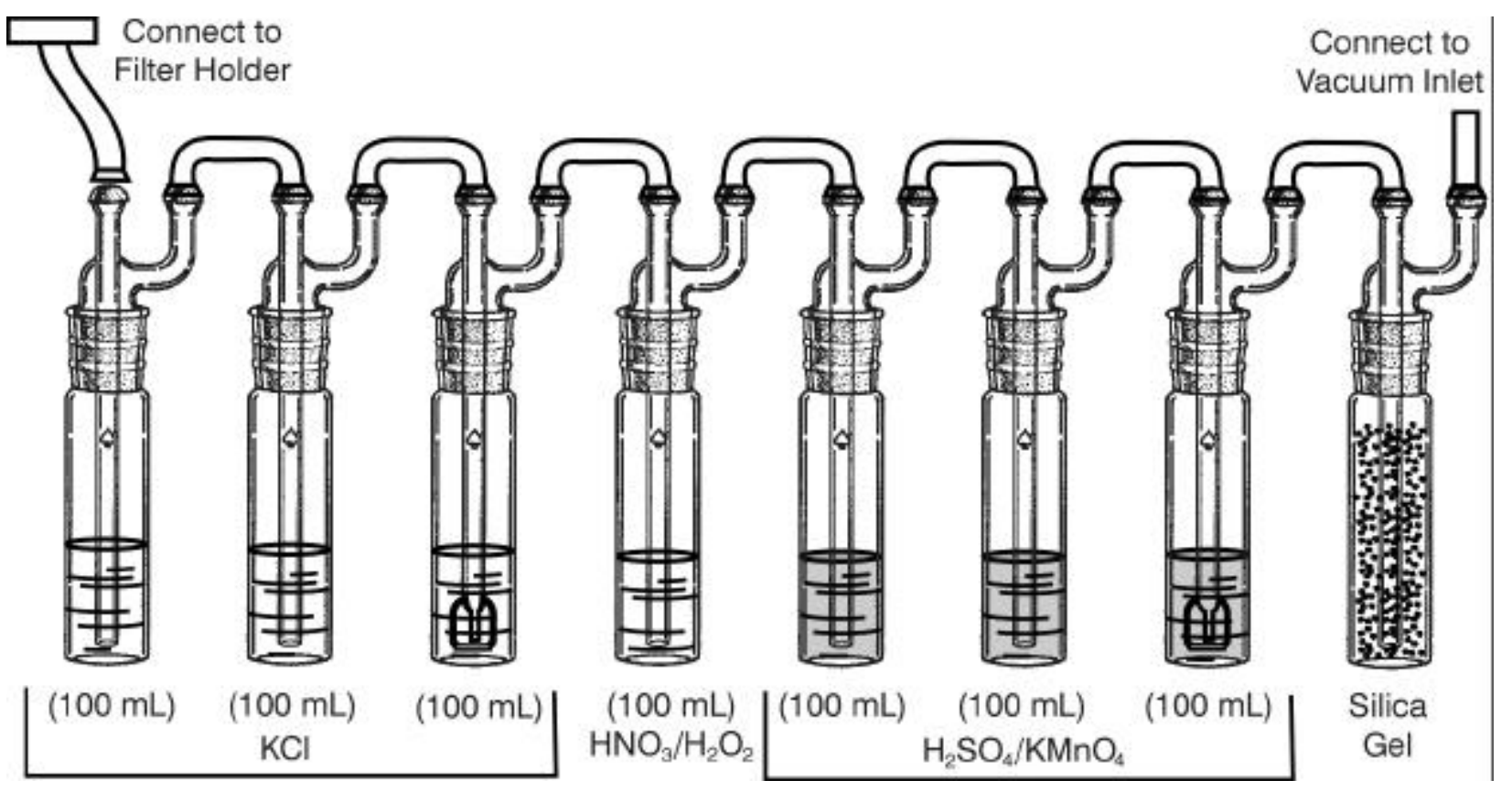

Figure 2. Schematic of the Ontario Hydro mercury speciation method sampling train. 
The solutions were analyzed on-site using a Leeman CVAA instrument. The particulate fraction, which was taken back to the EERC, was analyzed first using an $\mathrm{HCl}-\mathrm{HF}$ microwave digestion procedure followed by CVAA analysis for mercury. A schematic of the teardown of the sample train and the different fractions is shown in Figure 3.

For each of the three liquid solutions of the Ontario Hydro method, prior to analyses, a different preparation procedure must be used. The preparation steps for each solution are described below.

KCl Solution. The $\mathrm{KCl}$ sample fractions are immediately preserved with acidified $\mathrm{KMnO}_{4}$ after sampling. This solution is then digested using a potassium persulfate digest procedure.

$\mathrm{HNO}_{3}-\mathrm{H}_{2} \mathrm{O}_{2}$ Solution. The solution is first preserved with $10 \% \mathrm{v} / \mathrm{v} \mathrm{HCl}$, then combined with $\mathrm{H}_{2} \mathrm{SO}_{4}-\mathrm{KMnO}_{4}$ solution until a purple color persists. At this point, hydroxylamine sulfate is added until the solution becomes clear.

$\mathrm{H}_{2} \mathrm{SO}_{4}-\mathrm{KMnO}_{4}$ Solution. Hydroxylamine sulfate is added to the $\mathrm{KMnO}_{4}-\mathrm{H}_{2} \mathrm{SO}_{4}$ sample until the solution turns clear.

1. Rinse filter holder and connector with $0.1 \mathrm{~N} \mathrm{HNO}_{3}$.

2. Add $\mathrm{H}_{2} \mathrm{SO}_{4} / \mathrm{KMnO}_{4}$ to each impinger bottle until purple color remains.

3. Rinse with $0.1 \mathrm{~N} \mathrm{HNO}_{3}$.

4. Rinse with $8 \mathrm{~N} \mathrm{HCl}$ if brown residue remains.

5. Final rinse with $0.1 \mathrm{~N} \mathrm{HNO}_{3}$.

Rinse Bottles Sparingly with

$-0.1 \mathrm{~N} \mathrm{HNO}_{3}$

$-8 \mathrm{~N} \mathrm{HCl}$

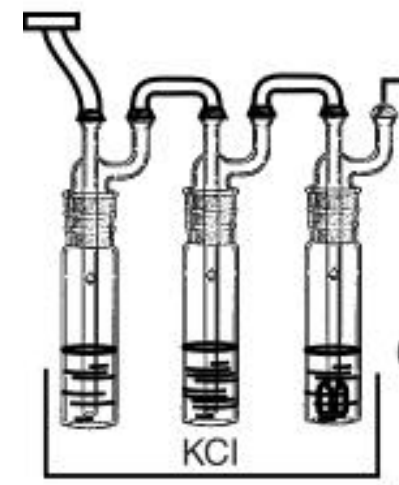

Rinse with $0.1 \mathrm{~N} \mathrm{HNO}_{3}$

- $0.1 \mathrm{~N} \mathrm{HNO}_{3}$
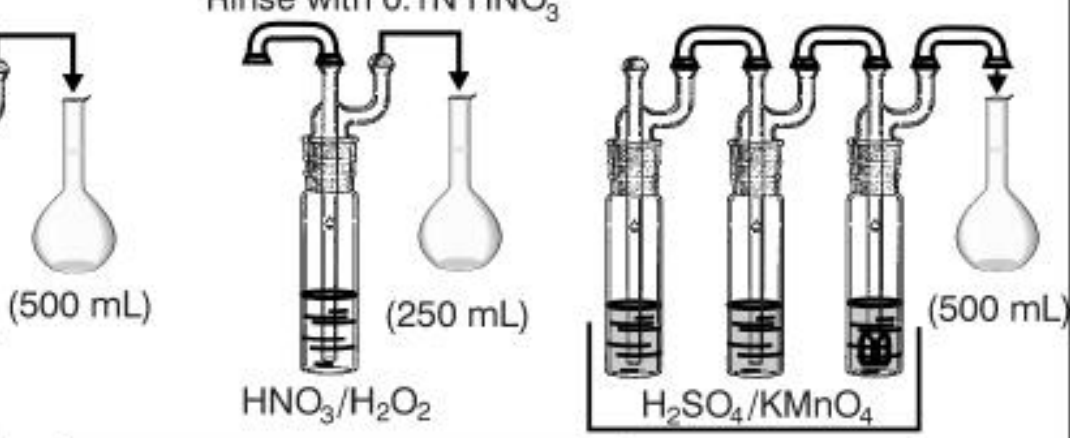

Rinse All U-Tubes with $0.1 \mathrm{~N} \mathrm{HNO}_{3}$

Figure 3. Teardown schematic of the Ontario Hydro mercury speciation method sampling train. 
For the Ontario Hydro method, the $\mathrm{KCl}$ fraction results are reported as $\mathrm{Hg}^{2+}$, and the sum of the mercury measured in the $\mathrm{HNO}_{3}-\mathrm{H}_{2} \mathrm{O}_{2}$ solution and $\mathrm{H}_{2} \mathrm{SO}_{4}-\mathrm{KMnO}_{4}$ solution is reported as $\mathrm{Hg}^{0}$. The mercury measured on the filter ash is defined as particulate-bound mercury. The exact form of the mercury on the particulate matter is still unknown.

\subsection{Semtech $\mathrm{Hg} 2000$ Analyzer}

A Semtech Hg 2000 mercury CEM manufactured by Semtech Metallurgy AB, Lund, Sweden, was used at the stack location. The instrument measures $\mathrm{Hg}^{0}$ on a real-time basis using a Zeeman-shifted ultraviolet sensor. The Zeeman shift detection technology eliminates interference from $\mathrm{SO}_{2}$ absorption. Because the instrument is designed to measure only $\mathrm{Hg}^{0}$, to get total mercury, the other forms of mercury $\left(\mathrm{Hg}^{2+}\right)$ must be converted to $\mathrm{Hg}^{0}$. This is done by passing the flue gas first through a carbonate trap to remove the $\mathrm{SO}_{2}$ and then a stannous chloride solution. The $\mathrm{SO}_{2}$ must be removed because it interferes with the ability of stannous chloride to convert $\mathrm{Hg}^{2+}$ to $\mathrm{Hg}^{0}$. The operating range of the instrument is $0.3 \mu \mathrm{g} / \mathrm{Nm}^{3}$ to $20 \mathrm{mg} / \mathrm{Nm}^{3}$. The Semtech $\mathrm{Hg} 2000$ has been certified by TUEV Rheinland for determining compliance with the German legal limit of $50 \mu \mathrm{g} / \mathrm{Nm}^{3}$ for total mercury from waste incinerators.

\subsection{Oxygen Concentration, Flue Gas Velocity, and Moisture}

To determine the $\mathrm{O}_{2}$ levels at each sample location, an Orsat procedure was used. Flue gas velocity, moisture, and flow rate determinations were performed according to EPA Methods 2 and 4 in conjunction with the Ontario Hydro method.

\subsection{Quality Assurance/Quality Control (QA/QC)}

An overall QA/QC program in place at the EERC is designed to maintain overall data integrity. However, additional procedures were instituted specifically for this project.

\subsubsection{Instrument Setup and Calibration}

The instrument used in the field for mercury determination was a Leeman Labs PS200 CVAA. To measure mercury, the instrument was set up for absorption at $253.7 \mathrm{~nm}$ with a carrier gas of nitrogen and $10 \% \mathrm{w} / \mathrm{v}$ stannous chloride in $10 \% \mathrm{v} / \mathrm{v} \mathrm{HCl}$ as the reductant. Each day, the drying tube and acetate trap were replaced and the tubing checked. The rinse container was cleaned and filled with fresh solution of $10 \% \mathrm{v} / \mathrm{v} \mathrm{HCl}$. After the pump and lamp were turned on 
and warmed up for 45 minutes, the aperture was set to manufacturer specifications. A four-point calibration curve was then completed using matrix-matched standards. The detector response for a given standard was logged and compared to specifications to ensure the instrument had been properly set up. A QC standard of a known analyte concentration was analyzed immediately after the instrument was standardized in order to verify the calibration. This QC standard was prepared from a different stock than the calibration standards. It was required that the values obtained read within $5 \%$ of the true value before the instrument was used. After the initial QC standardizations were completed, standards were run every five samples to check the slope of the calibration curve. All samples were run in duplicate, and one in every ten samples was spiked to verify analyte recovery. A QC chart is maintained at the EERC to monitor the long-term precision of the instrument.

\subsubsection{Presampling Preparation}

All data sheets, volumetric flasks, and petri dishes used for sample recovery were marked with preprinted labels. The liquid samples were recovered into premarked volumetric flasks and logged, then analyzed on-site. The filter samples were placed in premarked petri dishes and taken back to the EERC, where they were analyzed using mixed-acid digestion techniques. The labels contained identifying data, including date, time, run number, sample port location, and the name of the sampler.

\subsubsection{Glassware and Plasticware Cleaning and Storage}

All glass volumetric flasks and transfer pipets used in the preparation of analytical reagents and calibration standards were designated Class A to meet federal specifications. Prior to being used for the sampling, all glassware was washed with hot, soapy water, then rinsed with deionized water three times, soaked in $10 \% \mathrm{~V} / \mathrm{v}$ nitric acid for a minimum of $4 \mathrm{hr}$, rinsed an additional three times with deionized water, and dried. The glassware was then stored in closed containers until it was used at the plant.

\subsubsection{Analytical Reagents}

All acids that were used for the analysis of mercury were trace metal-grade. Other chemicals that were used in the preparation of analytical reagents were analytical reagent-grade. The calibration standards used for instrument calibration and the QC standards used for 
calibration verification were purchased commercially and certified to be accurate within $\pm 0.5 \%$ and were traceable to NIST standard reference materials.

\subsubsection{Blanks}

As part of the QA/QC procedures, four field blanks were completed. A field blank is defined as a complete impinger train including all glassware and solutions taken out to the field during sampling and exposed to ambient conditions. These sample trains are then taken apart and the solutions recovered and analyzed in the same manner as those sample trains used for sampling activities. If the field blank shows contamination above instrument background, steps must be taken to eliminate or reduce the contamination to below background levels. However, in all cases, the field blanks taken during the sampling activities at Site E-29 were shown to be insignificant, as shown in Table 5.

\section{TABLE 5}

Results of Mercury Speciation Field Blanks

\begin{tabular}{cccc}
\hline Day & KCl Solution, $\boldsymbol{\mu g} / \mathbf{L}$ & $\mathbf{H}_{\mathbf{2}} \mathbf{O}_{\mathbf{2}}$ Solution, $\boldsymbol{\mu g} / \mathbf{L}$ & $\mathbf{K M n O}_{\mathbf{4}}$ Solution, $\boldsymbol{\mu g} / \mathbf{L}$ \\
\hline 1 & $<0.03$ & $<0.03$ & $<0.03$ \\
2 & $<0.03$ & $<0.03$ & $<0.03$ \\
3 & $<0.03$ & $<0.03$ & $<0.03$ \\
4 & $<0.03$ & $<0.03$ & $<0.03$ \\
\hline
\end{tabular}

All acids, chemical reagents, and deionized water used for mercury determination were analyzed for background levels of mercury. Each time a new batch of reagents was prepared, an aliquot was immediately taken and analyzed for mercury. Again, no mercury contamination was found.

\subsubsection{Spiked Samples}

In order to ensure that adequate levels of accuracy were maintained, spiked samples were also submitted for analysis. These samples were made up independently of the chemist doing the analyses. The spikes were required to be within $15 \%$ of the true value. If the value is not within the specified limits, then the instrument is recalibrated and the samples reanalyzed. The spiking solutions were from a stock separate from the calibration standard stock. The analytical results for 
the spiked samples are shown in Table 6. As can be seen, with only a few exceptions, the analyses of these spikes are easily within the tolerance specified.

TABLE 6

Results of Mercury Speciation Field Spikes

\begin{tabular}{|c|c|c|c|c|c|c|c|c|c|}
\hline \multirow[b]{2}{*}{ Date } & \multicolumn{3}{|c|}{$\underline{\text { KCl Solution }}$} & \multicolumn{3}{|c|}{$\underline{\mathbf{H}}_{2} \underline{\mathbf{O}}_{2}$ Solution } & \multicolumn{3}{|c|}{$\underline{\mathrm{KMnO}}_{4}{ }_{4}$ Solution } \\
\hline & $\begin{array}{c}\text { Measured } \\
\text { Value, } \\
\text { ppb }\end{array}$ & $\begin{array}{c}\text { Spike, } \\
\text { ppb }\end{array}$ & $\begin{array}{c}\text { Spike } \\
\text { Recovery, } \\
\%\end{array}$ & $\begin{array}{c}\text { Measured } \\
\text { Value, } \\
\text { ppb }\end{array}$ & $\begin{array}{c}\text { Spike, } \\
\text { ppb }\end{array}$ & $\begin{array}{c}\text { Spike } \\
\text { Recovery, } \\
\%\end{array}$ & $\begin{array}{c}\text { Measured } \\
\text { Value, } \\
\text { ppb }\end{array}$ & $\begin{array}{c}\text { Spike, } \\
\text { ppb }\end{array}$ & $\begin{array}{c}\text { Spike } \\
\text { Recovery, } \\
\%\end{array}$ \\
\hline $10-15-98$ & 14.70 & 15 & 98.0 & \multirow[t]{2}{*}{3.595} & \multirow[t]{2}{*}{4} & \multirow[t]{2}{*}{89.9} & 4.51 & 5 & 90.2 \\
\hline $10-15-98$ & 9.94 & 10 & 99.4 & & & & 4.86 & 5 & 97.2 \\
\hline $10-15-98$ & 10.03 & 10 & 100.3 & 3.87 & 4 & 90.8 & 5.32 & 5 & 106.4 \\
\hline $10-16-98$ & 15.12 & 15 & 100.8 & 3.60 & 4 & 90.0 & 4.40 & 5 & 88.0 \\
\hline $10-16-98$ & 10.22 & 10 & 102.2 & 3.72 & 4 & 93.0 & 4.71 & 5 & 94.2 \\
\hline $10-16-98$ & 10.51 & 10 & 105.1 & 3.78 & 4 & 94.5 & 5.13 & 5 & 102.6 \\
\hline $10-17-98$ & 13.85 & 15 & 92.3 & 3.94 & 4 & 98.5 & 4.03 & 5 & 80.6 \\
\hline $10-17-98$ & 9.79 & 10 & 97.9 & 4.38 & 5 & 87.6 & 4.65 & 5 & 93.0 \\
\hline $10-17-98$ & 9.77 & 10 & 97.7 & 3.64 & 4 & 91.0 & 4.94 & 5 & 96.8 \\
\hline $10-17-98$ & 10.15 & 10 & 101.5 & 5.75 & 5 & 115.0 & & & \\
\hline $10-18-98$ & 13.35 & 15 & 89.0 & 4.48 & 5 & 86.2 & 4.38 & 5 & 87.6 \\
\hline $10-18-98$ & 9.53 & 10 & 95.3 & 5.12 & 5 & 102.4 & 4.84 & 5 & 96.8 \\
\hline $10-18-98$ & 9.57 & 10 & 95.7 & 5.30 & 5 & 106.0 & 4.35 & 5 & 87.0 \\
\hline \multirow[t]{3}{*}{$10-18-98$} & & & & 5.86 & 5 & 117.2 & & & \\
\hline & \multirow{2}{*}{\multicolumn{2}{|c|}{$\begin{array}{l}\text { Average } \\
\text { Std. Dev. }\end{array}$}} & 98.1 & \multirow{2}{*}{\multicolumn{2}{|c|}{$\begin{array}{l}\text { Average } \\
\text { Std. Dev. }\end{array}$}} & 97.5 & \multirow{2}{*}{\multicolumn{2}{|c|}{$\begin{array}{l}\text { Average } \\
\text { Std. Dev. }\end{array}$}} & 93.5 \\
\hline & & & 4.3 & & & 10.0 & & & 7.3 \\
\hline
\end{tabular}

\subsection{MERCURY SPECIATION RESULTS}

This section presents the flue gas mercury speciation results for the more formal validation tests and the mercury removal across the FGD system. All data are based on $20^{\circ} \mathrm{C}$ and dry conditions. The original data sheets for the flue gas mercury are provided in Appendix A.

\subsection{Ontario Hydro Mercury Speciation Validation Results}

The more formal validation of the Ontario Hydro mercury speciation method used a modification of EPA Method 301. As described earlier in Section 3.0, only five sets of quadtrains rather than six were used for the validation test. Analyte spiking was used in two impingers sets of 
each quadtrain (one-half of the total samples). The entire data set is shown in Table 7, and the statistical results are shown in Tables 8 and 9.

TABLE 7

Mercury Speciation Quadtrain Sampling Results Using the Ontario Hydro Method ${ }^{1}$

\begin{tabular}{|c|c|c|c|c|c|c|c|c|c|c|c|}
\hline Date & $\begin{array}{l}\text { Quad- } \\
\text { train }\end{array}$ & $\begin{array}{c}\text { Leak } \\
\text { Check }\end{array}$ & $\begin{array}{l}\text { Withou } \\
\text { Hg on } \\
\text { Filter, } \\
\mu \mathrm{g} / \mathrm{Nm}^{3}\end{array}$ & $\begin{array}{c}\mathrm{Hg}^{2+}, \\
\mu \mathrm{g} / \mathrm{Nm}^{3}\end{array}$ & $\begin{array}{c}\text { piking } \\
\mathrm{Hg}^{0}, \\
\mu \mathrm{g} / \mathrm{Nm}^{3}\end{array}$ & $\begin{array}{c}\text { Total } \\
\mathrm{Hg}, \\
\mu \mathrm{g} / \mathrm{Nm}^{3}\end{array}$ & $\begin{array}{c}\text { Leak } \\
\text { Check }\end{array}$ & $\begin{array}{r}\text { With } \\
\quad(\underline{\mathrm{sp}} \\
\mathrm{Hg} \text { on } \\
\text { Filter, } \\
\mu \mathrm{g} / \mathrm{Nm}^{3}\end{array}$ & $\begin{array}{l}\text { Analyte } \mathrm{S} \\
\text { ke subtra } \\
\mathrm{Hg}^{2+}, \\
\mu \mathrm{g} / \mathrm{Nm}^{3}\end{array}$ & $\begin{array}{l}\begin{array}{l}\text { iking } \\
\text { ted) }\end{array} \\
\quad \mathrm{Hg}^{0} \text {, } \\
\mu \mathrm{g} / \mathrm{Nm}^{3}\end{array}$ & $\begin{array}{c}\text { Total } \\
\mathrm{Hg}, \\
\mu \mathrm{g} / \mathrm{Nm}^{3} \\
\end{array}$ \\
\hline $10-15-98$ & 1 & Yes & 0.01 & 10.34 & 4.77 & 15.12 & Yes & 0.01 & 8.94 & 5.26 & 14.20 \\
\hline $10-15-98$ & 1 & No & 0.01 & 5.32 & 4.88 & 10.22 & Yes & 0.01 & 9.35 & 4.60 & 13.96 \\
\hline $10-16-98$ & 2 & Yes & 0.01 & 4.59 & 2.43 & 7.03 & No & 0.01 & 2.01 & 3.96 & 5.98 \\
\hline $10-16-98$ & 2 & Yes & 0.01 & 5.93 & 4.06 & 10.00 & Yes & 0.01 & 3.46 & 3.97 & 7.43 \\
\hline $10-17-98$ & 3 & Yes & 0.01 & 9.27 & 2.51 & 11.79 & No & 0.01 & 1.42 & 3.76 & 5.18 \\
\hline $10-17-98$ & 3 & Yes & 0.01 & 8.44 & 2.31 & 10.76 & Yes & 0.01 & 5.65 & 2.20 & 7.85 \\
\hline $10-18-98$ & 4 & Yes & 0.01 & 8.52 & 2.92 & 11.45 & Yes & 0.01 & 8.38 & 3.40 & 11.78 \\
\hline $10-18-98$ & 4 & Yes & 0.00 & 7.81 & 2.32 & 10.13 & Yes & 0.00 & 8.48 & 2.90 & 11.38 \\
\hline $10-18-98$ & 5 & Yes & 0.01 & 10.93 & 4.20 & 15.14 & Yes & 0.01 & 10.84 & 2.34 & 13.18 \\
\hline $10-18-98$ & 5 & Yes & 0.00 & 10.81 & 4.26 & 15.07 & Yes & 0.00 & 8.90 & 4.18 & 13.09 \\
\hline
\end{tabular}

${ }^{1}$ Results are presented on a dry basis and normal conditions $\left(20^{\circ} \mathrm{C}\right.$, and 1 atmosphere of pressure).

TABLE 8

Statistical Results for Precision for the Quadtrain Data from the Ontario Hydro Method

\begin{tabular}{|c|c|c|c|c|c|c|}
\hline & \multicolumn{3}{|c|}{$\begin{array}{l}\text { With Analyte Spiking } \\
\text { (spike subtracted) }\end{array}$} & \multicolumn{3}{|c|}{ Without Analyte Spiking } \\
\hline & $\begin{array}{c}\mathrm{Hg}^{2+} \\
\mu \mathrm{g} / \mathrm{Nm}^{3}\end{array}$ & $\begin{array}{c}\mathrm{Hg}^{0}, \\
\mu \mathrm{g} / \mathrm{Nm}^{3}\end{array}$ & $\begin{array}{l}\text { Total } \mathrm{Hg}, \\
\mu \mathrm{g} / \mathrm{Nm}^{3}\end{array}$ & $\begin{array}{c}\mathrm{Hg}^{2+}, \\
\mu \mathrm{g} / \mathrm{Nm}^{3}\end{array}$ & $\begin{array}{c}\mathrm{Hg}^{0}, \\
\mu \mathrm{g} / \mathrm{Nm}^{3}\end{array}$ & $\begin{array}{l}\text { Total } \mathrm{Hg}, \\
\mu \mathrm{g} / \mathrm{Nm}^{3}\end{array}$ \\
\hline Std. Dev. & 0.81 & 0.82 & 0.19 & 0.61 & 0.62 & 1.21 \\
\hline$\% \mathrm{RSD}$ & 8.83 & 21.81 & 1.49 & 7.40 & 19.77 & 10.55 \\
\hline Mean & 9.15 & 3.78 & 12.93 & 8.29 & 3.13 & 11.42 \\
\hline
\end{tabular}




\section{TABLE 9}

Statistical Results for Bias for the Quadtrain Data from the Ontario Hydro Method

\begin{tabular}{lccc}
\hline & $\begin{array}{c}\mathrm{Hg}^{2+}, \\
\mu g / \mathrm{Nm}^{3}\end{array}$ & $\begin{array}{c}\mathrm{Hg}^{0}, \\
\mu \mathrm{g} / \mathrm{Nm}^{3}\end{array}$ & $\begin{array}{c}\text { Total Hg, } \\
\mu \mathrm{g} / \mathrm{Nm}^{3}\end{array}$ \\
\cline { 2 - 4 } Bias & 0.86 & 0.65 & 1.51 \\
Pooled Std. Dev. & 1.01 & 1.03 & 1.22 \\
t-value & 0.850 & 0.635 & 1.237 \\
t-statistic & 2.571 & 2.571 & 2.571 \\
\hline
\end{tabular}

Leaks developing across the quadtrain probe, filter, or impinger train can be a major problem in doing quadtrain sampling. This proved to be a problem in the testing at Site E-29. As shown in Table 7, several of the sample trains did not pass the leak check at the end of the sampling period. As a result, the leaks resulted in the mercury concentration being less than would be expected. These samples were not used to determine the relative standard deviation and bias results as shown in Tables 8 and 9. Originally, only four quadtrains were planned, but a fifth was done to compensate for the lost sample trains due to leaks in the system.

Also based on the speciation results, there does appear to be some variability from day to day. As was shown earlier in Figure 1, there is variability in sulfur content of the coal. It is not unreasonable to assume there could be variability in the mercury content as well. However, the statistical results show that the Ontario Hydro method passes the criteria established in EPA Method 301. The relative standard deviation (RSD) is clearly less than 50\% in all cases. Also, the calculations show that there is no statistical bias (the pooled standard deviation is less than the t-statistic). Based on the mercury speciation results, the mercury generated by this coal was approximately $70 \% \mathrm{Hg}^{2+}$ and $30 \% \mathrm{Hg}^{0}$. This ratio tended to remain constant regardless of the day-to-day variability in the data.

One issue that has been extensively discussed with respect to mercury speciation methods is the temperature at which the particulate filter should be maintained. For these tests, the filters were out of stack (EPA Method 5), but the filters and probes were maintained at the temperature of the flue gas $\left(\sim 320^{\circ} \mathrm{F}\right)$. As shown in Table 7 , the amount of mercury measured on the filter was insignificant. However, because the samples were taken at the outlet of the ESPs, the dust loading was also low. 


\subsection{Statistical Error/Variability Associated with the Ontario Hydro Method}

Data variability results from two sources. The first is actual variability in the compound or element being measured, and the second is error associated with the measurement. The use of paired or quadtrains is designed to help eliminate process variability and determine sample error. Based on very extensive pilot-scale testing using the Ontario Hydro method, the error that can be expected is approximately $10 \%$ of the measured value if the measured value is $>1.0 \mu \mathrm{g} / \mathrm{Nm}^{3}$. These pilot-scale tests were essential conducted under ideal conditions. It is expected that sampling in the field will result in increased error: people are more cramped; sampling ports are often not ideal; samples must be sent off-site; more chances exist for contamination error, etc. From the field data collected to date using the Ontario Hydro Method, the error associated with paired trains (eliminating process variability) has been between $10 \%$ and $20 \%$. For example, in two field tests done by the EERC at plants firing North Dakota lignites, the maximum variability for six measurements at the FGD outlet was $12 \%$ and $11 \%$.

It has been found that the greatest source of error in the Ontario Hydro procedure is not in the sampling but in the preparation of the impinger solutions following sampling. The preparation steps include 1) tearing down the impinger train, 2) transferring the solutions to flasks or bottles, and 3) digesting of the solutions so that they can be analyzed using CVAA. In the field tests completed in North Dakota, the sample preparation and analysis was done in the field. If qualified people are doing the work, overall measurement error will be reduced, since the sample preparation is done immediately and samples are not shipped off-site.

In the tests completed at Site E-29, the quadtrain sampling resulted in a maximum variability (\%RSD) of $22 \%$. Although the sample preparation and analyses were done on-site, this is on the high end of the expected variability. However, the process variability was also high, as shown by the $\mathrm{SO}_{2}$ data in Figure 1 and the mercury CEM data discussed later in this report (Section 5.4). The use of bundled quadtrains also can create the potential for data variability because they are clumsy to use and are prone to leaks. Indeed, several of the tests did not pass the leak check that must be completed prior to sampling and after sampling is completed. Nevertheless, as stated earlier, the Ontario Hydro method clearly passes the statistical criteria established in EPA Method 301. 


\subsection{Mercury Removal Across the FGD System}

The Ontario Hydro mercury speciation results at the inlet and the outlet of the FGD are shown in Table 10 and, graphically, in Figure 4. It shows in Table 8 that the FGD system removed about $88 \%$ of the $\mathrm{Hg}^{2+}$, but little if any $\mathrm{Hg}^{0}$. This is in agreement with all of the mercury data that have been collected in the last several years across wet FGD systems. The overall mercury removal across the FGD system was about 51\%. Although it appears that there was an increase in $\mathrm{Hg}^{0}$ across the FGD, this may not be the case for several reasons. First, all of the data are presented on an as-measured $\mathrm{O}_{2}$ basis. There were not enough $\mathrm{O}_{2}$ measurements taken at either the stack or the FGD inlet sample point to ensure an accurate $\mathrm{O}_{2}$ concentration; therefore, $\mathrm{O}_{2}$ was not taken into account. Secondly, the inlet to the FGD and stack samples were not taken simultaneously, and there was variability in the data. This is shown in Figure 4 by the relatively large error bars on the FGD inlet data. It is also possible that the measured inlet $\mathrm{Hg}^{0}$ concentration was low. This can occur if there is oxidation of $\mathrm{Hg}^{0}$ across the sample filter. Although the particulate loading on the sample filter was low, it was not zero. Previous research has shown that particulate matter can convert $\operatorname{Hg}^{0}$ to $\operatorname{Hg}^{2+}(2,4)$.

TABLE 10

Mercury Speciation Results Across the FGD System

\begin{tabular}{|c|c|c|c|c|c|c|c|c|}
\hline \multirow[b]{3}{*}{ Date } & \multicolumn{3}{|c|}{ Outlet of FGD } & \multicolumn{3}{|c|}{ Inlet of FGD } & \multirow[b]{2}{*}{$\mathrm{Hg}^{2+}$} & \multirow[b]{2}{*}{ Total Hg } \\
\hline & & & Total & & & Total & & \\
\hline & $\begin{array}{c}\mathrm{Hg}^{2+}, \\
\mu \mathrm{g} / \mathrm{Nm}^{3}\end{array}$ & $\begin{array}{c}\mathrm{Hg}^{0}, \\
\mu \mathrm{g} / \mathrm{Nm}^{3}\end{array}$ & $\begin{array}{c}\mathrm{Hg}, \\
\mu \mathrm{g} / \mathrm{Nm}^{3}\end{array}$ & $\begin{array}{c}\mathrm{Hg}^{2+} \\
\mu \mathrm{g} / \mathrm{Nm}^{3}\end{array}$ & $\begin{array}{c}\mathrm{Hg}^{0}, \\
\mu \mathrm{g} / \mathrm{Nm}^{3}\end{array}$ & $\begin{array}{c}\mathrm{Hg}, \\
\mu \mathrm{g} / \mathrm{Nm}^{3}\end{array}$ & $\begin{array}{c}\text { Removed, } \\
\%\end{array}$ & $\begin{array}{c}\text { Removed, } \\
\%\end{array}$ \\
\hline $10-16-98$ & 1.23 & 4.25 & 5.47 & & & & & \\
\hline $10-16-98$ & 0.77 & 3.86 & 4.63 & & & & & \\
\hline Avg. & 1.00 & 4.05 & 5.05 & 4.66 & 3.49 & 8.15 & 78.5 & 38.0 \\
\hline Std. & 0.32 & 0.27 & 0.59 & 1.24 & 0.92 & 1.61 & & \\
\hline $10-17-98$ & 1.15 & 4.35 & 5.50 & & & & & \\
\hline $10-17-98$ & 0.49 & 4.19 & 4.67 & & & & & \\
\hline Avg. & 0.82 & 4.27 & 5.09 & 7.79 & 2.34 & 10.13 & 89.5 & 49.7 \\
\hline Std. & 0.47 & 0.11 & 0.58 & 1.90 & 0.15 & 2.04 & & \\
\hline $10-17-98$ & 0.82 & 3.88 & 4.70 & & & & & \\
\hline $10-17-98$ & 0.57 & 4.52 & 5.09 & & & & & \\
\hline Avg. & 0.70 & 4.20 & 4.90 & 9.33 & 3.32 & 12.65 & 92.5 & 61.3 \\
\hline Std. & 0.17 & 0.45 & 0.28 & 1.30 & 0.82 & 1.80 & & \\
\hline
\end{tabular}




\subsection{Semtech Hg 2000 CEM Results}

The Semtech CEM was used at the inlet of the FGD system. Although the instrument was developed to only measure $\mathrm{Hg}^{0}$, the instrument was able to measure total mercury by including a conversion system designed at the EERC. To provide mercury speciation data, the conversion system was periodically bypassed to measure $\mathrm{Hg}^{0}$ and, by difference, the concentration of $\mathrm{Hg}^{2+}$ in the flue gas could be determined. A comparison between the Semtech CEM data and the Ontario Hydro method data is shown graphically in Figures 5 through 8. As can be seen from the four graphs, the CEM results for both total $\mathrm{Hg}$ and $\mathrm{Hg}^{0}$ compare quite well with the results obtained using the Ontario Hydro method. On Day 4, the carbonate trap of the conversion system was intentionally bypassed to determine the effect it would have on the conversion of $\mathrm{Hg}^{2+}$ to $\mathrm{Hg}^{0}$. As had been speculated, the resulting high levels of $\mathrm{SO}_{2}$ in the sample gas stream interfered with the ability of stannous chloride solution to convert $\mathrm{Hg}^{2+}$ to $\mathrm{Hg}^{0}$. As seen in Figure 8, eventually no conversion occurred, and the measured total $\mathrm{Hg}$ was the same as the measured concentration of the $\mathrm{Hg}^{0}$. It should be noted that the Semtech and Ontario Hydro method results are presented on the same basis (dry but not corrected for $\mathrm{O}_{2}$ ).

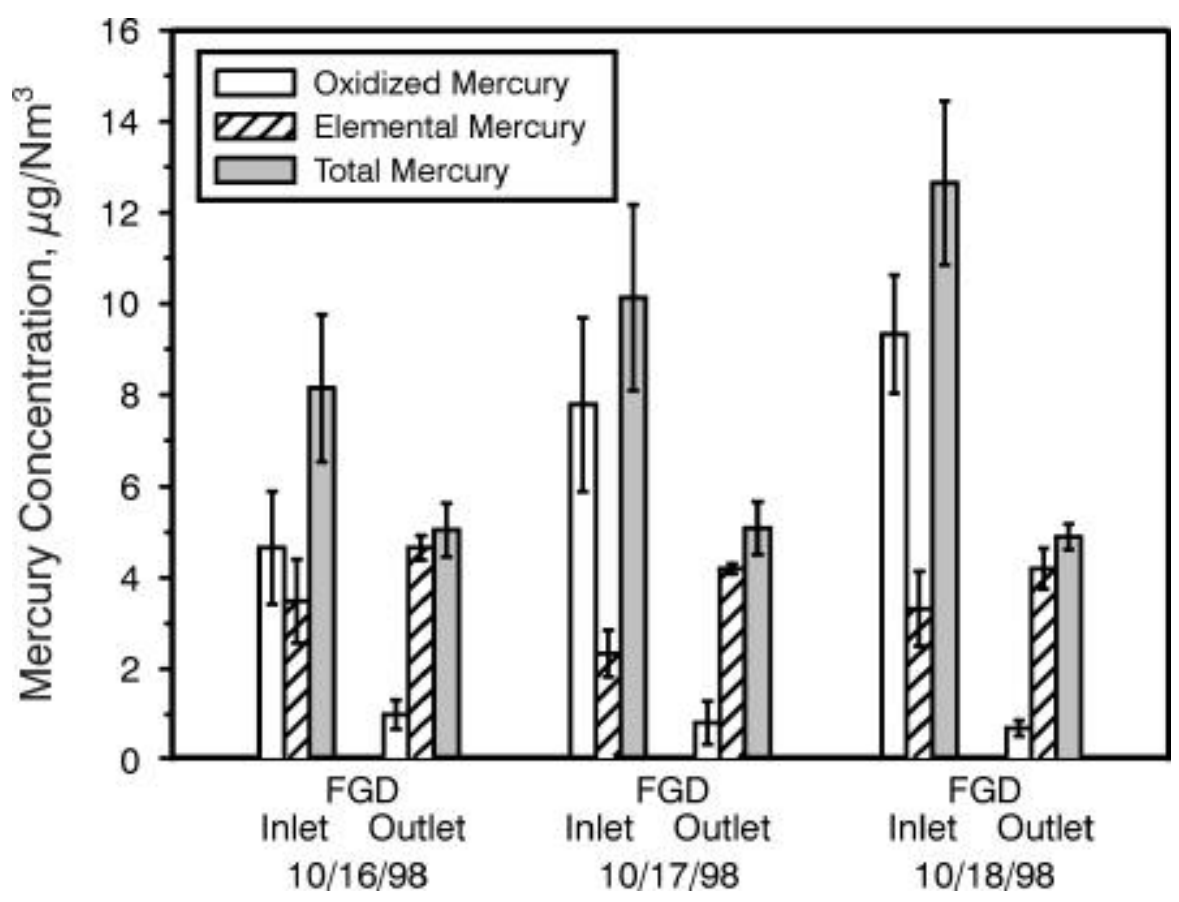

Figure 4. The change in vapor-phase speciated mercury across the FGD system. 


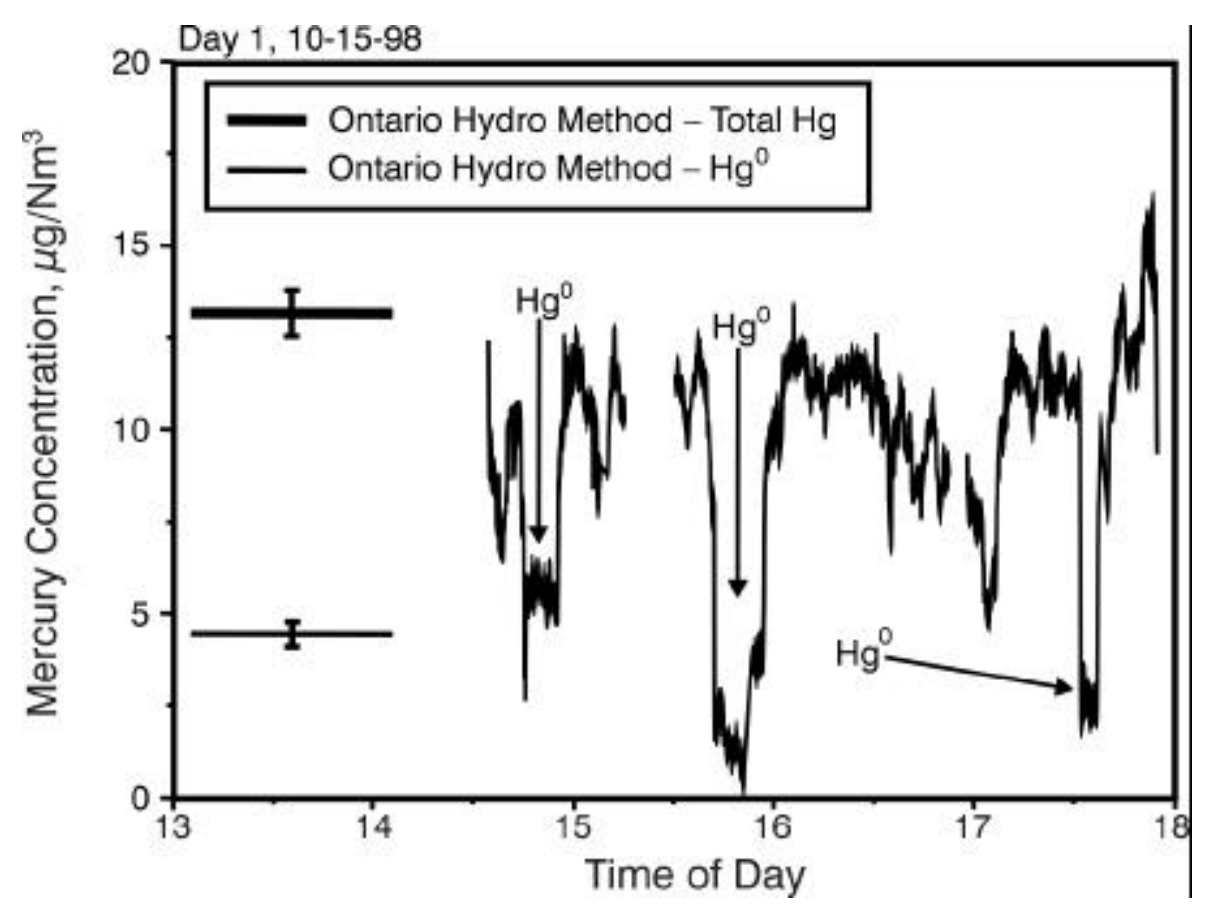

Figure 5. Direct comparison between Semtech mercury CEM and Ontario Hydro method for Day 1.

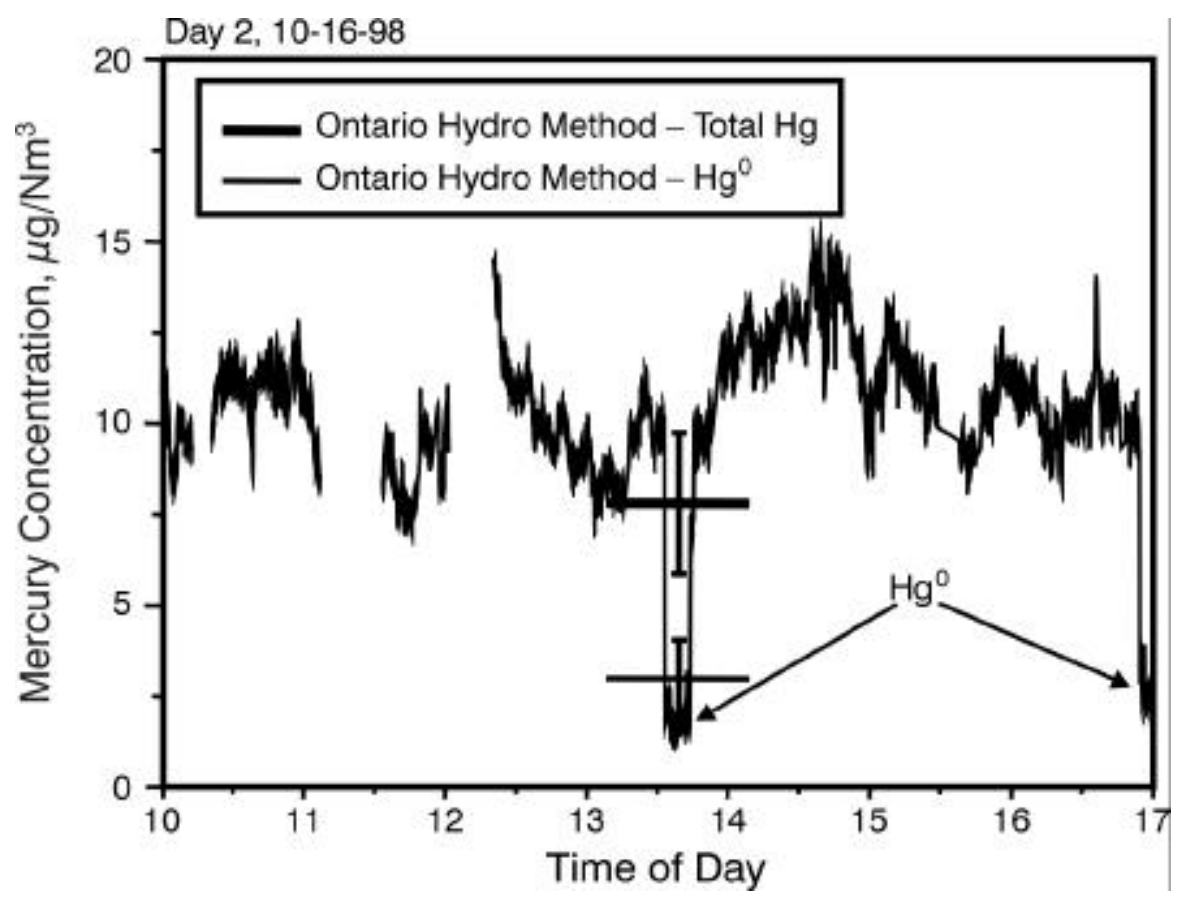

Figure 6. Direct comparison between Semtech mercury CEM and Ontario Hydro method for Day 2. 


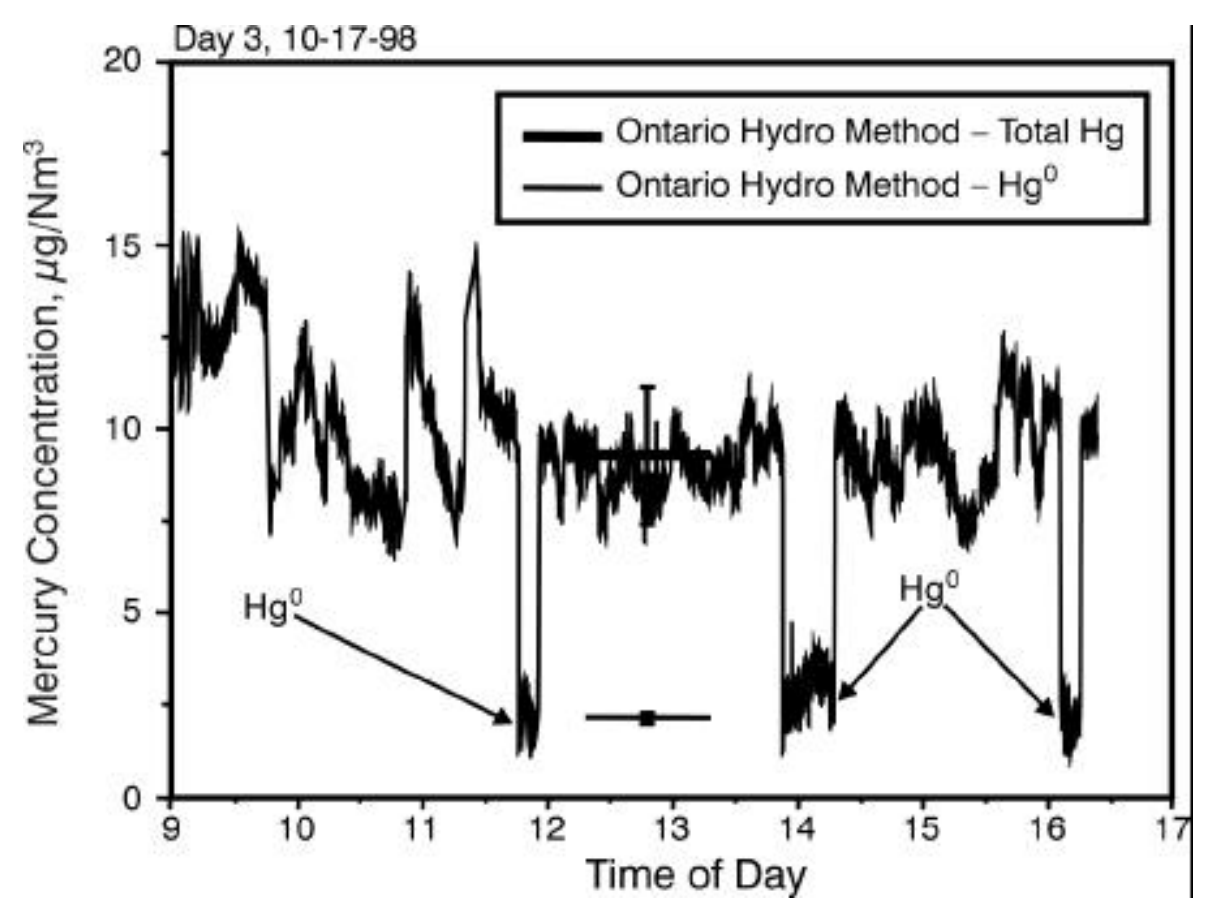

Figure 7. Direct comparison between Semtech mercury CEM and Ontario Hydro method for Day 3.

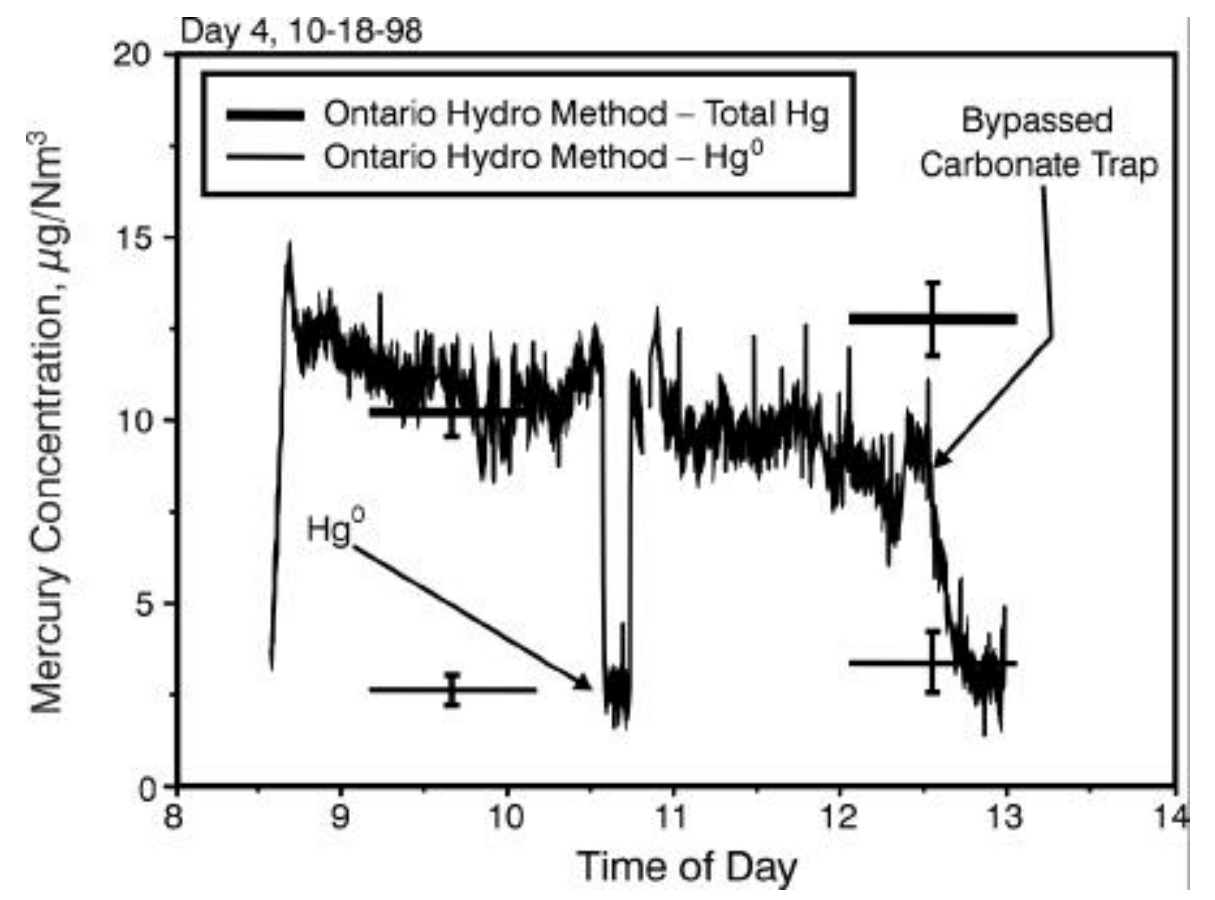

Figure 8. Direct comparison between Semtech mercury CEM and Ontario Hydro method for Day 4. 


\subsection{CONCLUSIONS}

On the basis of the results from the Ontario Hydro mercury speciation sampling project at Site E-29, the following conclusions can be drawn:

- The Ontario Hydro method results were well within the statistical criteria established by EPA Method 301. The method is valid for measuring mercury speciation in the field.

- The mercury emitted at the stack was about $10 \% \mathrm{Hg}^{2+}$ and $90 \% \mathrm{Hg}^{0}$.

- No mercury was captured on the filters of the sampling train at either the FGD inlet or the stack.

- The FGD system removed about $88 \%$ of the $\mathrm{Hg}^{2+}$. The overall mercury removal of the FGD system was $51 \%$.

- The Semtech Hg 2000 gave total mercury results comparable to those obtained using the Ontario Hydro mercury speciation sampling method for both total $\mathrm{Hg}$ and $\mathrm{Hg}^{0}$.

\subsection{REFERENCES}

1. U.S. Environmental Protection Agency. Airlink Web Site at: http://www.epa.gov/airlinks/ (accessed 1/22/99).

2. Laudal, D.L.; Galbreath, K.C.; Heidt M.K. A State-of-the-Art Review of Flue Gas Mercury Speciation Methods. EPRI Report No. TR-107080 3471; Nov 1996.

3. Laudal, D.L.; Heidt, M.K. Evaluation of Flue Gas Mercury Speciation Methods. EPRI Report No. TR-108988; Dec 1997.

4. Carey, T.R.; Hargrove, O.W., Jr.; Richardson, C.F.; Chang, R.; Meserole, F.B. Factors Affecting Mercury Control in Utility Flue Gas Using Sorbent Injection. Presented at the Air \& Waste Management Association 90th Annual Meeting \& Exhibition, June 1997, Toronto, ON, Canada; Paper No. 97-WA72A.05. 


\section{APPENDIX A ORIGINAL DATA SHEETS}

\section{A-1 Original Mercury Data A-2 Field Blanks and Field Spikes A-3 Sampling Data}


A-1 Original Mercury Data 


\begin{tabular}{|c|c|c|c|c|c|c|c|}
\hline Sample ID & Date & & $\begin{array}{c}\text { Probe } \\
\text { Rinse } \\
\text { ug/Nm3 }\end{array}$ & $\begin{array}{c}\mathrm{KCl} \\
\mathrm{ug} / \mathrm{Nm} 3\end{array}$ & $\begin{array}{c}\mathrm{H} 2 \mathrm{O} 2 \\
\mathrm{ug} / \mathrm{Nm} 3\end{array}$ & $\begin{array}{l}\mathrm{KMnO} 4 \\
\mathrm{ug} / \mathrm{Nm} 3\end{array}$ & $\begin{array}{c}\text { Total } \\
\text { Mercury } \\
\text { ug/Nm3 }\end{array}$ \\
\hline ZM-D1-OH-1 & $10 / 15 / 1998$ & Inlet & 0.01 & 17.36 & 0.07 & 7.80 & 25.24 \\
\hline ZM-D1-OH-2 & $10 / 15 / 1998$ & Inlet & 0.01 & 9.47 & 0.07 & 4.30 & 13.85 \\
\hline ZM-D1-OH-3 & 10/15/1998 & Inlet & 0.01 & 17.41 & 0.01 & 7.14 & 24.57 \\
\hline ZM-D1-OH-4 & $10 / 15 / 1998$ & Inlet & 0.01 & 4.92 & 0.04 & 4.47 & 9.44 \\
\hline ZM-D2-OH-1 & $10 / 16 / 1998$ & Inlet & 0.01 & 4.21 & 0.06 & 2.17 & 6.45 \\
\hline ZM-D2-OH-2 & 10/16/1998 & Inlet & 0.01 & 10.12 & 0.45 & 5.96 & 16.54 \\
\hline ZM-D2-OH-3 & $10 / 16 / 1998$ & Inlet & 0.01 & 5.45 & 0.36 & 3.37 & 9.19 \\
\hline ZM-D2-OH-4 & $10 / 16 / 1998$ & Inlet & 0.01 & 11.27 & 0.56 & 5.78 & 17.62 \\
\hline ZM-D2-OH-5 & $10 / 16 / 1998$ & Outlet & 0.00 & 3.64 & 0.01 & 1.04 & 4.69 \\
\hline ZM-D2-OH-6 & $10 / 16 / 1998$ & Outlet & 0.00 & 0.66 & 0.01 & 3.29 & 3.96 \\
\hline ZM-D3-OH-1 & $10 / 17 / 1998$ & Inlet & 0.01 & 8.50 & 0.04 & 2.26 & 10.81 \\
\hline ZM-D3-OH-2 & $10 / 17 / 1998$ & Inlet & 0.01 & 7.74 & 0.43 & 1.69 & 9.87 \\
\hline ZM-D3-OH-3 & $10 / 17 / 1998$ & Inlet & 0.01 & 15.10 & 0.23 & 9.33 & 24.67 \\
\hline ZM-D3-OH-4 & $10 / 17 / 1998$ & Inlet & 0.01 & 20.78 & 0.04 & 7.49 & 28.32 \\
\hline ZM-D3-OH-5A & $10 / 17 / 1998$ & Outlet & 0.01 & 0.99 & 0.01 & 3.72 & 4.73 \\
\hline ZM-D3-OH-5B & $10 / 17 / 1998$ & Outlet & 0.01 & 0.42 & 0.00 & 3.60 & 4.03 \\
\hline ZM-D3-OH-6A & $10 / 17 / 1998$ & Outlet & 0.01 & 0.70 & 0.05 & 3.26 & 4.02 \\
\hline ZM-D3-OH-6B & $10 / 17 / 1998$ & Outlet & 0.01 & 0.49 & 0.01 & 3.85 & 4.36 \\
\hline ZM-D4-OH-1-Q1 & $10 / 18 / 1998$ & Inlet & 0.01 & 7.76 & 0.03 & 2.63 & 10.43 \\
\hline ZM-D4-OH-2-Q1 & $10 / 18 / 1998$ & Inlet & 0.01 & 7.13 & 0.42 & 1.70 & 9.26 \\
\hline ZM-D4-OH-3-Q1 & $10 / 18 / 1998$ & Inlet & 0.01 & 13.46 & 1.46 & 5.69 & 20.62 \\
\hline ZM-D4-OH-4-Q1 & $10 / 18 / 1998$ & Inlet & 0.01 & 13.35 & 1.52 & 5.07 & 19.95 \\
\hline ZM-D4-OH-5-Q2 & $10 / 18 / 1998$ & Inlet & 0.01 & 9.87 & 0.27 & 3.52 & 13.67 \\
\hline ZM-D4-OH-6-Q2 & $10 / 18 / 1998$ & Inlet & 0.01 & 15.35 & 0.80 & 4.63 & 20.79 \\
\hline ZM-D4-OH-7-Q2 & 10/18/1998 & Inlet & 0.01 & 9.76 & 0.49 & 3.36 & 13.62 \\
\hline ZM-D4-OH-8-Q2 & $10 / 18 / 1998$ & Inlet & 0.01 & 13.52 & 1.10 & 5.97 & 20.60 \\
\hline
\end{tabular}

Values are below LLQ.

Spiked sample.

\begin{tabular}{|cccc|}
\hline & $\begin{array}{r}\mathrm{KCl} \\
\text { Spike } \\
\text { ug/Nm3 }\end{array}$ & $\begin{array}{c}\mathrm{H} 2 \mathrm{O} 2 \\
\text { Spike } \\
\text { ug/Nm3 }\end{array}$ & $\begin{array}{c}\text { KMnO4 } \\
\text { Spike } \\
\text { ug/Nm3 }\end{array}$ \\
ZM-D1-OH-1 & 9.20 & None & 3.07 \\
ZM-D1-OH-3 & 8.92 & None & 2.97 \\
ZM-D2-OH-2 & 8.27 & None & 2.76 \\
ZM-D2-OH-4 & 8.10 & None & 2.70 \\
ZM-D3-OH-3 & 16.95 & None & 5.65 \\
ZM-D3-OH-4 & 16.52 & None & 5.51 \\
ZM-D4-OH-3-Q1 & 5.75 & 1.15 & 2.87 \\
ZM-D4-OH-4-Q1 & 5.63 & 1.13 & 2.82 \\
ZM-D4-OH-6-Q2 & 5.52 & 0.55 & 2.76 \\
ZM-D4-OH-8-Q2 & 5.47 & 0.55 & 2.74 \\
\hline
\end{tabular}


Final Results

November 20, 1998

Set Number: 49769

Request Date: Monday, November 16, 1998

Fund\#: 4426

Due Date: Monday, November 30, 1998

PI: Dennis Laudal

Set Description: Zimmer Station Ash Filter

Contact Person: Dennis Laudal

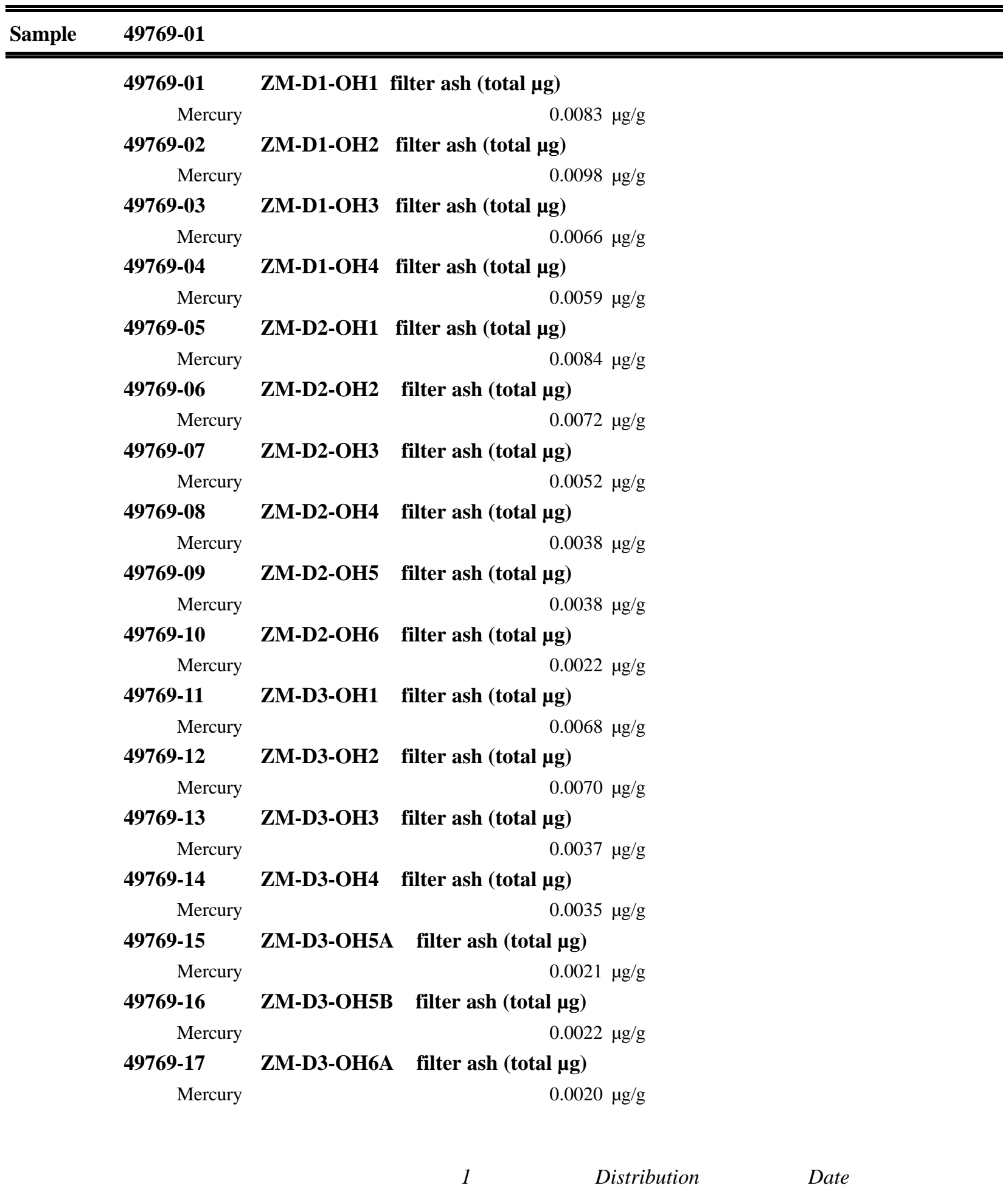




\begin{tabular}{|c|c|c|c|}
\hline \multirow[t]{2}{*}{ Sample } & \multicolumn{3}{|l|}{ 49769-18 } \\
\hline & 49769-18 & ZM-D3-OH6B & filter ash (total $\mu \mathrm{g})$ \\
\hline & Mercury & & $0.0011 \mu \mathrm{g} / \mathrm{g}$ \\
\hline & 49769-19 & ZM-D4-OHQ1 & filter ash (total $\mu \mathrm{g})$ \\
\hline & Mercury & & $0.0050 \mu \mathrm{g} / \mathrm{g}$ \\
\hline & 49769-20 & ZM-D4-OH2Q1 & filter ash (total $\mu \mathrm{g})$ \\
\hline & Mercury & & $0.0036 \mu \mathrm{g} / \mathrm{g}$ \\
\hline & 49769-21 & ZM-D4-OH3Q1 & filter ash (total $\mu \mathrm{g})$ \\
\hline & Mercury & & $0.0036 \mu \mathrm{g} / \mathrm{g}$ \\
\hline & 49769-22 & ZM-D4-OH4Q1 & filter ash (total $\mu \mathrm{g})$ \\
\hline & Mercury & & $0.0034 \mu \mathrm{g} / \mathrm{g}$ \\
\hline & 49769-23 & ZM-D4-OH5Q2 & filter ash (total $\mu \mathrm{g})$ \\
\hline & Mercury & & $0.0060 \mu \mathrm{g} / \mathrm{g}$ \\
\hline & 49769-24 & ZM-D4-OH6Q2 & filter ash (total $\mu \mathrm{g})$ \\
\hline & Mercury & & $0.0042 \mu \mathrm{g} / \mathrm{g}$ \\
\hline & 49769-25 & ZM-D4-OH7Q2 & filter ash (total $\mu \mathrm{g})$ \\
\hline & Mercury & & $0.0014 \mu \mathrm{g} / \mathrm{g}$ \\
\hline & 49769-26 & ZM-D4-OH8Q2 & filter ash (total $\mu \mathrm{g})$ \\
\hline & Mercury & & $0.0033 \mu \mathrm{g} / \mathrm{g}$ \\
\hline
\end{tabular}




\section{A-2 Field Blanks and Field Spikes}




\section{MERCURY ANALYSIS}

DATE: $\quad 10 / 17 / 1998$

LOCATION: ZIMMER POWER PLANT

\begin{tabular}{|c|c|c|c|c|}
\hline LAB \# & SAMPLE ID & SAMPLE TYPE & VOLUME, ml & CONCENTRATION, ug/L \\
\hline $1017-3$ & ZM-D1-FB & $\mathrm{KCl}$ & 500 & $<0.03$ \\
\hline $1017-4$ & ZM-D1-FB & $\mathrm{H} 2 \mathrm{O} 2$ & 250 & $<0.03$ \\
\hline $1017-5$ & ZM-D1-FB & $\mathrm{KMnO} 4$ & 500 & $<0.03$ \\
\hline $1017-6$ & ZM-D1-FB-SPK & $\mathrm{KCl}$ & 500 & 14.7 \\
\hline $1017-7$ & ZM-D1-FB-SPK & $\mathrm{H} 2 \mathrm{O} 2$ & 250 & $<0.03$ \\
\hline $1017-8$ & ZM-D1-FB-SPK & $\mathrm{KMnO} 4$ & 500 & 4.51 \\
\hline $1017-9$ & ZM-D1-OH-1 & Probe rinse & 200 & $<0.03$ \\
\hline $1017-10$ & ZM-D1-OH-1 (SPIKED) & $\mathrm{KCl}$ & 500 & 28.28 \\
\hline $1017-11$ & ZM-D1-OH-1 & $\mathrm{H} 2 \mathrm{O} 2$ & 250 & 0.24 \\
\hline $1017-12$ & ZM-D1-OH-1 (SPIKED) & $\mathrm{KMnO} 4$ & 500 & 12.7 \\
\hline $1017-12 \mathrm{a}$ & ZM-D1-OH-1 & $\mathrm{KMnO} 4$ rinse & 100 & $<0.03$ \\
\hline $1017-13$ & ZM-D1-OH-2 & Probe rinse & 200 & $<0.03$ \\
\hline $1017-14$ & ZM-D1-OH-2 & $\mathrm{KCl}$ & 500 & 15.17 \\
\hline $1017-15$ & ZM-D1-OH-2 & $\mathrm{H} 2 \mathrm{O} 2$ & 250 & 0.22 \\
\hline $1017-16$ & ZM-D1-OH-2 & KMnO4 & 500 & 6.88 \\
\hline 1017-16a & ZM-D1-OH-2 & $\mathrm{KMnO} 4$ rinse & 200 & $<0.03$ \\
\hline $1017-17$ & ZM-D1-OH-3 & Probe rinse & 200 & $<0.03$ \\
\hline $1017-18$ & ZM-D1-OH-3 & $\mathrm{KCl}$ & 500 & 29.26 \\
\hline 1017-19 & ZM-D1-OH-3 & $\mathrm{H} 2 \mathrm{O} 2$ & 250 & $<0.03$ \\
\hline $1017-20$ & ZM-D1-OH-3 & KMnO4 & 500 & 12 \\
\hline $1017-21$ & ZM-D1-OH-4 & Probe rinse & 200 & $<0.03$ \\
\hline $1017-22$ & ZM-D1-OH-4 & $\mathrm{KCl}$ & 500 & 7.71 \\
\hline $1017-23$ & ZM-D1-OH-4 & $\mathrm{H} 2 \mathrm{O} 2$ & 250 & 0.12 \\
\hline $1017-24$ & ZM-D1-OH-4 & KMnO4 & 500 & 6.97 \\
\hline $1017-24 a$ & $\mathrm{ZM}-\mathrm{D} 1-\mathrm{OH}-4$ & $\mathrm{KMnO} 4$ rinse & 200 & 0.08 \\
\hline
\end{tabular}




\section{MERCURY ANALYSIS}

DATE: $\quad 10 / 17 / 1998$

LOCATION: ZIMMER POWER PLANT

LAB \# SAMPLE ID SAMPLE TYPE VOLUME, ml CONCENTRATION, ug/L

\begin{tabular}{|c|c|c|c|c|}
\hline $1017-25$ & ZM-D2-FB & $\mathrm{KCl}$ & 500 & $<0.03$ \\
\hline $1017-26$ & ZM-D2-FB & $\mathrm{H} 2 \mathrm{O} 2$ & 250 & $<0.03$ \\
\hline $1017-27$ & ZM-D2-FB & $\mathrm{KMnO} 4$ & 500 & $<0.03$ \\
\hline $1017-28$ & ZM-D2-FB-SPK & $\mathrm{KCl}$ & 500 & 15.12 \\
\hline $1017-29$ & ZM-D2-FB-SPK & $\mathrm{H} 2 \mathrm{O} 2$ & 250 & 3.6 \\
\hline $1017-30$ & ZM-D2-FB-SPK & $\mathrm{KMnO} 4$ & 500 & 4.4 \\
\hline $1017-31$ & ZM-D2-OH-1 & Probe rinse & 200 & $<0.03$ \\
\hline $1017-32$ & ZM-D2-OH-1 & $\mathrm{KCl}$ & 500 & 7.31 \\
\hline $1017-33$ & ZM-D2-OH-1 & $\mathrm{H} 2 \mathrm{O} 2$ & 250 & 0.21 \\
\hline $1017-34$ & ZM-D2-OH-1 & $\mathrm{KMnO} 4$ & 500 & 3.77 \\
\hline $1017-35$ & ZM-D2-OH-2 & Probe rinse & 100 & $<0.03$ \\
\hline $1017-36$ & ZM-D2-OH-2 (SPIKED) & $\mathrm{KCl}$ & 500 & 18.34 \\
\hline $1017-37$ & ZM-D2-OH-2 & $\mathrm{H} 2 \mathrm{O} 2$ & 250 & 1.63 \\
\hline $1017-38$ & ZM-D2-OH-2 (SPIKED) & KMnO4 & 500 & 10.8 \\
\hline 1017-39 & ZM-D2-OH-3 & Probe rinse & 100 & $<0.03$ \\
\hline $1017-40$ & ZM-D2-OH-3 & $\mathrm{KCl}$ & 500 & 9.66 \\
\hline $1017-41$ & ZM-D2-OH-3 & $\mathrm{H} 2 \mathrm{O} 2$ & 250 & 1.26 \\
\hline $1017-42$ & ZM-D2-OH-3 & KMnO4 & 500 & 5.97 \\
\hline $1017-43$ & ZM-D2-OH-4 & Probe rinse & 100 & $<0.03$ \\
\hline $1017-44$ & ZM-D2-OH-4 (SPIKED) & $\mathrm{KCl}$ & 500 & 20.86 \\
\hline $1017-45$ & ZM-D2-OH-4 & $\mathrm{H} 2 \mathrm{O} 2$ & 250 & 2.07 \\
\hline $1017-46$ & ZM-D2-OH-4 (SPIKED) & $\mathrm{KMnO} 4$ & 250 & 10.7 \\
\hline $1017-47$ & ZM-D2-OH-5 & Probe rinse & 200 & $<0.03$ \\
\hline $1017-48$ & ZM-D2-OH-5 & $\mathrm{KCl}$ & 500 & 8.77 \\
\hline $1017-49$ & ZM-D2-OH-5 & $\mathrm{H} 2 \mathrm{O} 2$ & 250 & $<0.03$ \\
\hline $1017-50$ & ZM-D2-OH-5 & $\mathrm{KMnO} 4$ & 500 & 2.51 \\
\hline $1017-59$ & ZM-D2-OH-5 & Filter rinse & 200 & $<0.03$ \\
\hline $1017-51$ & ZM-D2-OH-6 & Probe rinse & 200 & $<0.03$ \\
\hline $1017-52$ & ZM-D2-OH-6 & $\mathrm{KCl}$ & 500 & 1.6 \\
\hline $1017-53$ & ZM-D2-OH-6 & $\mathrm{H} 2 \mathrm{O} 2$ & 250 & $<0.03$ \\
\hline $1017-54$ & ZM-D2-OH-6 & $\mathrm{KMnO} 4$ & 500 & 7.95 \\
\hline $1017-60$ & ZM-D2-OH-6 & Filter rinse & 200 & $<0.03$ \\
\hline $1017-56$ & ZM-D2-OH-7 & $\mathrm{KCl}$ & 500 & 3.6 \\
\hline $1017-57$ & ZM-D2-OH-7 & $\mathrm{H} 2 \mathrm{O} 2$ & 250 & 0.38 \\
\hline $1017-58$ & ZM-D2-OH-7 & $\mathrm{KMnO} 4$ & 500 & 6.19 \\
\hline
\end{tabular}




\section{MERCURY ANALYSIS}

DATE: $\quad 10 / 18 / 1998$

LOCATION: ZIMMER POWER PLANT

\begin{tabular}{|c|c|c|c|c|}
\hline LAB \# & SAMPLE ID & SAMPLE TYPE & VOLUME, ml & CONCENTRATION, ug/L \\
\hline $1018-1$ & ZM-D3-FB & $\mathrm{KCl}$ & 500 & $<0.03$ \\
\hline $1018-2$ & ZM-D3-FB & $\mathrm{H} 2 \mathrm{O} 2$ & 250 & $<0.03$ \\
\hline $1018-3$ & ZM-D3-FB & $\mathrm{KMnO} 4$ & 500 & $<0.03$ \\
\hline $1018-4$ & ZM-D3-FB-SPK & $\mathrm{KCl}$ & 500 & 13.85 \\
\hline $1018-5$ & ZM-D3-FB-SPK & $\mathrm{H} 2 \mathrm{O} 2$ & 250 & 3.94 \\
\hline $1018-6$ & ZM-D3-FB-SPK & $\mathrm{KMnO} 4$ & 500 & 4.03 \\
\hline $1018-7$ & ZM-D3-OH-1 & Probe rinse & 200 & $<0.03$ \\
\hline $1018-8$ & ZM-D3-OH-1 & $\mathrm{KCl}$ & 500 & 15.9 \\
\hline $1018-9$ & ZM-D3-OH-1 & $\mathrm{H} 2 \mathrm{O} 2$ & 250 & 0.14 \\
\hline 1018-10 & ZM-D3-OH-1 & $\mathrm{KMnO} 4$ & 500 & 4.22 \\
\hline 1018-11 & ZM-D3-OH-2 & Probe rinse & 200 & $<0.03$ \\
\hline 1018-12 & ZM-D3-OH-2 & $\mathrm{KCl}$ & 500 & 14.25 \\
\hline 1018-13 & ZM-D3-OH-2 & $\mathrm{H} 2 \mathrm{O} 2$ & 250 & 1.58 \\
\hline 1018-14 & ZM-D3-OH-2 & $\mathrm{KMnO} 4$ & 500 & 3.13 \\
\hline 1018-15 & ZM-D3-OH-3 & Probe rinse & 100 & $<0.03$ \\
\hline 1018-16 & ZM-D3-OH-3 & $\mathrm{KCl}$ (SPIKED) & 500 & 26.7 \\
\hline 1018-17 & ZM-D3-OH-3 & $\mathrm{H} 2 \mathrm{O} 2$ & 250 & 0.81 \\
\hline 1018-18 & ZM-D3-OH-3 & KMnO4 (SPIKED) & 500 & 16.5 \\
\hline 1018-19 & ZM-D3-OH-4 & Probe rinse & 100 & $<0.03$ \\
\hline $1018-20$ & ZM-D3-OH-4 & $\mathrm{KCl}$ (SPIKED) & 500 & 37.65 \\
\hline $1018-21$ & ZM-D3-OH-4 & $\mathrm{H} 2 \mathrm{O} 2$ & 250 & 0.15 \\
\hline $1018-22$ & ZM-D3-OH-4 & KMnO4 (SPIKED) & 500 & 13.6 \\
\hline $1018-23$ & ZM-D3-OH-5A & Probe rinse & 500 & $<0.03$ \\
\hline $1018-24$ & ZM-D3-OH-5A & $\mathrm{KCl}$ & 500 & 2.42 \\
\hline $1018-25$ & ZM-D3-OH-5A & $\mathrm{KCl}$ rinse & 100 & 0.23 \\
\hline $1018-26$ & ZM-D3-OH-5A & $\mathrm{H} 2 \mathrm{O} 2$ & 250 & $<0.03$ \\
\hline $1018-27$ & ZM-D3-OH-5A & $\mathrm{KMnO} 4$ & 500 & 9.27 \\
\hline $1018-28$ & ZM-D3-OH-5B & Probe rinse & 250 & $<0.03$ \\
\hline $1018-29$ & ZM-D3-OH-5B & $\mathrm{KCl}$ & 500 & 1.74 \\
\hline 1018-30 & ZM-D3-OH-5B & $\mathrm{H} 2 \mathrm{O} 2$ & 250 & 0.23 \\
\hline 1018-31 & ZM-D3-OH-5B & $\mathrm{KMnO} 4$ & 500 & 8.07 \\
\hline $1018-32$ & ZM-D3-OH-6A & Probe rinse & 500 & $<0.03$ \\
\hline $1018-33$ & ZM-D3-OH-6A & $\mathrm{KCl}$ & 500 & 1.05 \\
\hline 1018-34 & ZM-D3-OH-6A & $\mathrm{KCl}$ rinse & 100 & $<0.03$ \\
\hline $1018-35$ & ZM-D3-OH-6A & $\mathrm{H} 2 \mathrm{O} 2$ & 250 & $<0.03$ \\
\hline $1018-36$ & ZM-D3-OH-6A & $\mathrm{KMnO} 4$ & 500 & 9.05 \\
\hline 1018-37 & ZM-D3-OH-6B & Probe rinse & 500 & $<0.03$ \\
\hline $1018-38$ & ZM-D3-OH-6B & $\mathrm{KCl}$ & 500 & 1.22 \\
\hline 1018-39 & ZM-D3-OH-6B & $\mathrm{H} 2 \mathrm{O} 2$ & 250 & $<0.03$ \\
\hline $1018-40$ & ZM-D3-OH-6B & $\mathrm{KMnO} 4$ & 500 & 9.58 \\
\hline $1018-42$ & ZM-D3-OH-7 & $\mathrm{KCl}$ & 500 & 9.72 \\
\hline $1018-43$ & ZM-D3-OH-7 & $\mathrm{H} 2 \mathrm{O} 2$ & 250 & 0.35 \\
\hline $1018-44$ & ZM-D3-OH-7 & $\mathrm{KMnO} 4$ & 500 & 4.29 \\
\hline
\end{tabular}


DATE: $\quad 10 / 28 / 1998$

LOCATION: ZIMMER POWER PLANT

\begin{tabular}{|c|c|c|c|c|}
\hline LAB \# & SAMPLE ID & SAMPLE TYPE & VOLUME, ml & CONCENTRATION, ug/L \\
\hline $1019-1$ & ZM-D4-FB & $\mathrm{KCl}$ & 500 & $<0.03$ \\
\hline $1019-2$ & ZM-D4-FB & $\mathrm{H} 2 \mathrm{O} 2$ & 250 & $<0.03$ \\
\hline 1019-3 & ZM-D4-FB & $\mathrm{KMnO} 4$ & 500 & $<0.03$ \\
\hline $1019-4$ & ZM-D4-FB-SPK & $\mathrm{KCl}$ & 500 & 13.35 \\
\hline $1019-5$ & ZM-D4-FB-SPK & $\mathrm{H} 2 \mathrm{O} 2$ & 250 & 4.48 \\
\hline $1019-6$ & ZM-D4-FB-SPK & $\mathrm{KMnO} 4$ & 500 & 4.38 \\
\hline 1019-7 & ZM-D4-OH-1-Q1 & Probe rinse & 200 & $<0.03$ \\
\hline $1019-8$ & ZM-D4-OH-1-Q1 & $\mathrm{KCl}$ & 500 & 13.57 \\
\hline $1019-9$ & ZM-D4-OH-1-Q1 & $\mathrm{H} 2 \mathrm{O} 2$ & 250 & 0.11 \\
\hline 1019-10 & ZM-D4-OH-1-Q1 & $\mathrm{KMnO} 4$ & 500 & 4.61 \\
\hline 1019-11 & ZM-D4-OH-2-Q1 & Probe rinse & 200 & $<0.03$ \\
\hline 1019-12 & ZM-D4-OH-2-Q1 & $\mathrm{KCl}$ & 500 & 13.02 \\
\hline 1019-13 & ZM-D4-OH-2-Q1 & $\mathrm{H} 2 \mathrm{O} 2$ & 250 & 1.54 \\
\hline 1019-14 & ZM-D4-OH-2-Q1 & $\mathrm{KMnO} 4$ & 500 & 3.1 \\
\hline 1019-15 & ZM-D4-OH-3-Q1 & Probe rinse & 100 & $<0.03$ \\
\hline 1019-16 & ZM-D4-OH-3-Q1 & $\mathrm{KCl}$ (SPIKED) & 500 & 23.38 \\
\hline 1019-17 & ZM-D4-OH-3-Q1 & H2O2 (SPIKED) & 250 & 5.09 \\
\hline 1019-18 & ZM-D4-OH-3-Q1 & KMnO4 (SPIKED) & 500 & 9.9 \\
\hline 1019-19 & ZM-D4-OH-4-Q1 & Probe rinse & 200 & $<0.03$ \\
\hline $1019-20$ & ZM-D4-OH-4-Q1 & $\mathrm{KCl}$ (SPIKED) & 500 & 23.66 \\
\hline 1019-21 & ZM-D4-OH-4-Q1 & H2O2 (SPIKED) & 250 & 5.41 \\
\hline $1019-22$ & ZM-D4-OH-4-Q1 & KMnO4 (SPIKED) & 500 & 9 \\
\hline $1019-23$ & ZM-D4-OH-5-Q2 & Probe rinse & 200 & $<0.03$ \\
\hline $1019-24$ & ZM-D4-OH-5-Q2 & $\mathrm{KCl}$ & 500 & 17.84 \\
\hline $1019-25$ & ZM-D4-OH-5-Q2 & $\mathrm{H} 2 \mathrm{O} 2$ & 250 & 0.96 \\
\hline $1019-26$ & ZM-D4-OH-5-Q2 & $\mathrm{KMnO} 4$ & 500 & 6.35 \\
\hline 1019-27 & ZM-D4-OH-6-Q2 & Probe rinse & 200 & $<0.03$ \\
\hline $1019-28$ & ZM-D4-OH-6-Q2 & $\mathrm{KCl}$ (SPIKED) & 500 & 27.84 \\
\hline $1019-29$ & ZM-D4-OH-6-Q2 & H2O2 (SPIKED) & 250 & 2.91 \\
\hline 1019-30 & ZM-D4-OH-6-Q2 & KMnO4 (SPIKED) & 500 & 8.39 \\
\hline 1019-31 & ZM-D4-OH-7-Q2 & Probe rinse & 200 & $<0.03$ \\
\hline 1019-32 & ZM-D4-OH-7-Q2 & $\mathrm{KCl}$ & 500 & 17.55 \\
\hline 1019-33 & ZM-D4-OH-7-Q2 & $\mathrm{H} 2 \mathrm{O} 2$ & 250 & 1.76 \\
\hline 1019-34 & ZM-D4-OH-7-Q2 & KMnO4 & 500 & 6.05 \\
\hline 1019-35 & ZM-D4-OH-8-Q2 & Probe rinse & 200 & $<0.03$ \\
\hline 1019-36 & ZM-D4-OH-8-Q2 & $\mathrm{KCl}$ (SPIKED) & 500 & 24.65 \\
\hline 1019-37 & ZM-D4-OH-8-Q2 & H2O2 (SPIKED) & 250 & 4.03 \\
\hline 1019-38 & ZM-D4-OH-8-Q2 & KMnO4 (SPIKED) & 500 & 10.9 \\
\hline 1019-39 & ZM-D4-AHin & Probe rinse & 200 & $<0.03$ \\
\hline $1019-40$ & ZM-D4-AHin & $\mathrm{KCl}$ & 500 & 12.56 \\
\hline 1019-41 & ZM-D4-AHin & $\mathrm{H} 2 \mathrm{O} 2$ & 250 & 0.42 \\
\hline $1019-42$ & ZM-D4-AHin & $\mathrm{KMnO} 4$ & 500 & 5.72 \\
\hline
\end{tabular}


SPIKE RECOVERIES FOR MERCURY ANALYSIS

\begin{tabular}{|c|c|c|c|c|c|c|c|}
\hline $\begin{array}{l}\text { DATE: } \\
\text { Calibr }\end{array}$ & $\begin{array}{l}\text { 10/17/1998 } \\
\text { on Standards: }\end{array}$ & & $1,5,10,20 \mathrm{ppb}$ & & 0.9995 & $\mathrm{QC}=4.12(4)$ & \\
\hline & & SAMPLE & SPIKE & SAMPLE & SPIKE & SPIKE & SPIKE \\
\hline LAB \# & SAMPLE ID & TYPE & AMOUNT (PPB) & READING (UG/L) & READING (ug/L) & LOCATION & RECOVERY \% \\
\hline $1017-6$ & ZM-D1-FB-SPK & $\mathrm{KCl}$ & 15 & 0 & 14.7 & FIELD & 98 \\
\hline $1017-6$ & ZM-D1-FB-SPK & $\mathrm{KCl}$ & 10 & 14.7 & 24.64 & $\mathrm{LAB}$ & 99.4 \\
\hline $1017-14$ & ZM-D1-OH-2 & $\mathrm{KCl}$ & 10 & 15.17 & 25.2 & $\mathrm{LAB}$ & 100.3 \\
\hline $1017-7$ & ZM-D1-FB-SPK & $\begin{array}{r}\mathrm{H} 2 \mathrm{O} 2 \\
\end{array}$ & 4 & MPI & 2.55 & LAB & 89.9 \\
\hline $1017-11$ & ZM-D1-OH-1 & $\mathrm{H} 2 \mathrm{O} 2$ & 4 & 0.24 & 3.87 & $\mathrm{LAB}$ & 90.75 \\
\hline $1017-8$ & ZM-D1-FB-SPK & $\mathrm{KMnO} 4$ & 5 & 0 & 4.51 & FIELD & 90.2 \\
\hline $1017-8$ & ZM-D1-FB-SPK & $\mathrm{KMnO} 4$ & 5 & 4.51 & 9.37 & LAB & 97.2 \\
\hline $1017-16$ & ZM-D1-OH-2 & $\mathrm{KMnO} 4$ & 5 & 6.88 & 12.2 & LAB & 106.4 \\
\hline DATE: $\mathrm{Ca}$ & $\begin{array}{l}\text { 10/17/1998 } \\
\text { ration Standards: }\end{array}$ & & $0,1,5,10,20 \mathrm{ppb}$ & & $\mathrm{R}=0.9995$ & $\mathrm{QC}=4.12(4)$ & \\
\hline LAB \# & SAMPLE ID & $\begin{array}{l}\text { SAMPLE } \\
\text { TYPE }\end{array}$ & $\begin{array}{c}\text { SPIKE } \\
\text { AMOUNT (PPB) }\end{array}$ & $\begin{array}{c}\text { SAMPLE } \\
\text { READING (UG/L) }\end{array}$ & $\begin{array}{c}\text { SPIKE } \\
\text { READING (ug/L) }\end{array}$ & $\begin{array}{c}\text { SPIKE } \\
\text { LOCATION }\end{array}$ & $\begin{array}{c}\text { SPIKE } \\
\text { RECOVERY \% }\end{array}$ \\
\hline $1017-28$ & ZM-D2-FB-SPK & $\mathrm{KCl}$ & 15 & 0 & 15.12 & FIELD & 100.8 \\
\hline $1017-28$ & ZM-D2-FB-SPK & $\mathrm{KCl}$ & 10 & 15.12 & 25.34 & LAB & 102.2 \\
\hline $1017-52$ & ZM-D2-OH-6 & $\mathrm{KCl}$ & 10 & 1.6 & 12.11 & LAB & 105.1 \\
\hline $1017-29$ & ZM-D2-FB-SPK & $\mathrm{H} 2 \mathrm{O} 2$ & 4 & 0 & 3.6 & FIELD & 90 \\
\hline $1017-29$ & ZM-D2-FB-SPK & $\mathrm{H} 2 \mathrm{O} 2$ & 4 & 3.6 & 7.32 & LAB & 93 \\
\hline $1017-41$ & ZM-D2-OH-3 & $\mathrm{H} 2 \mathrm{O} 2$ & 4 & 1.26 & 5.04 & LAB & 94.5 \\
\hline $1017-30$ & ZM-D2-FB-SPK & $\mathrm{KMnO} 4$ & 5 & 0 & 4.4 & FIELD & 88.1 \\
\hline $1017-30$ & ZM-D2-FB-SPK & $\mathrm{KMnO} 4$ & 5 & 4.4 & 9.11 & LAB & 94.2 \\
\hline $1017-42$ & ZM-D2-OH-3 & $\mathrm{KMnO} 4$ & 5 & 5.97 & 11.1 & LAB & $\begin{array}{r}102.6 \\
\text { Continued . . }\end{array}$ \\
\hline
\end{tabular}


SPIKE RECOVERIES FOR MERCURY ANALYSIS (Continued)

DATE: $\quad 10 / 18 / 1998$

Calibration Standards:

$0,1,5,10,20 \mathrm{ppb}$

$\mathrm{R}=0.9991$

$\mathrm{QC}=3.91(4)$

LAB \# SAMPLE ID

SAMPLE SPIKE AMOUNT

SAMPLE

SPIKE READING

SPIKE

TYPE

(PPB)

READING (UG/L)

(ug/L)

LOCATION

SPIKE

$\begin{array}{llrc}1018-4 & \text { ZM-D3-FB-SPK } & \mathrm{KCl} & 15 \\ 1018-4 & \text { ZM-D3-FB-SPK } & \mathrm{KCl} & 10 \\ 1018-24 & \text { ZM-D3-OH-5A } & \mathrm{KCl} & 10 \\ 1018-42 & \text { ZM-D3-OH-7 } & \mathrm{KCl} & 10 \\ 1018-5 & \text { ZM-D3-FB-SPK } & \mathrm{H} 2 \mathrm{O} 2 & 4 \\ 1018-5 & \text { ZM-D3-FB-SPK } & \mathrm{H} 2 \mathrm{O} 2 & 5 \\ 1018-9 & \text { ZM-D3-OH-1 } & \mathrm{H} 2 \mathrm{O} 2 & 4 \\ 1018-13 & \text { ZM-D3-OH-2 } & \mathrm{H} 2 \mathrm{O} 2 & 5 \\ 1018-6 & \text { ZM-D3-FB-SPK } & \text { KMnO4 } & 5 \\ 1018-6 & \text { ZM-D3-FB-SPK } & \text { KMnO4 } & 5 \\ 1018-10 & \text { ZM-D3-OH-1 } & \text { KMnO4 } & 5\end{array}$

0
13.85

13.85

23.64

FIELD
LAB

RECOVERY \%

2.42

12.19

LAB

92.33
97.9

9.72

19.87

LAB

97.7

0
3.94

FIELD

LAB

101.5

0.14

8.32

LAB

98.5

87.6

1.58

LAB

91

0

7.33

FIELD

LAB

115

4.03

4.03
8.68

LAB

80.6

9.16

93

DATE: $\quad 10 / 28 / 1998$

Calibration Standards:

$0,1,5,10,20 \mathrm{ppb}$

$\mathrm{R}=0.9997$

$\mathrm{QC}=3.96(4)$

LAB \# SAMPLE ID

SAMPLE SPIKE AMOUNT TYPE (PPB)

SAMPLE READING (UG/L)

SPIKE READING

SPIKE (ug/L)

LOCATION

SPIKE

RECOVERY \%

$\begin{array}{llrr}1019-4 & \text { ZM-D4-FB-SPK } & \text { KCl } & 15 \\ 1019-4 & \text { ZM-D4-FB-SPK } & \text { KCl } & 10 \\ 1019-24 & \text { ZM-D4-OH-5-Q2 } & \text { KCl } & 10 \\ 1019-5 & \text { ZM-D4-FB-SPK } & \text { H2O2 } & 5.2 \\ 1019-5 & \text { ZM-D4-FB-SPK } & \text { H2O2 } & 5 \\ 1019-9 & \text { ZM-D4-OH-1-Q1 } & \text { H2O2 } & 5 \\ 1019-29 & \text { ZM-D4-OH-6-Q2 } & \text { H2O2 } & 5 \\ 1019-6 & \text { ZM-D4-FB-SPK } & \text { KMnO4 } & 5 \\ 1019-6 & \text { ZM-D4-FB-SPK } & \text { KMnO4 } & 5 \\ 1019-34 & \text { ZM-D4-OH-7-Q2 } & \text { KMnO4 } & 5\end{array}$

0
13.35
17.84
0
4.48
0.11
2.91
0
4.38
6.05

13.35
22.88
27.41
4.48
9.6
5.41
8.77
4.38
9.22
10.4

FIELD
LAB
LAB
FIELD
LAB
LAB
LAB
FIELD
LAB
LAB

89

95.3

95.7

86.15

102.4

106

117.2

87.6

96.8

87 


\section{A-3 Sampling Data}


Ontario Hydro Stack

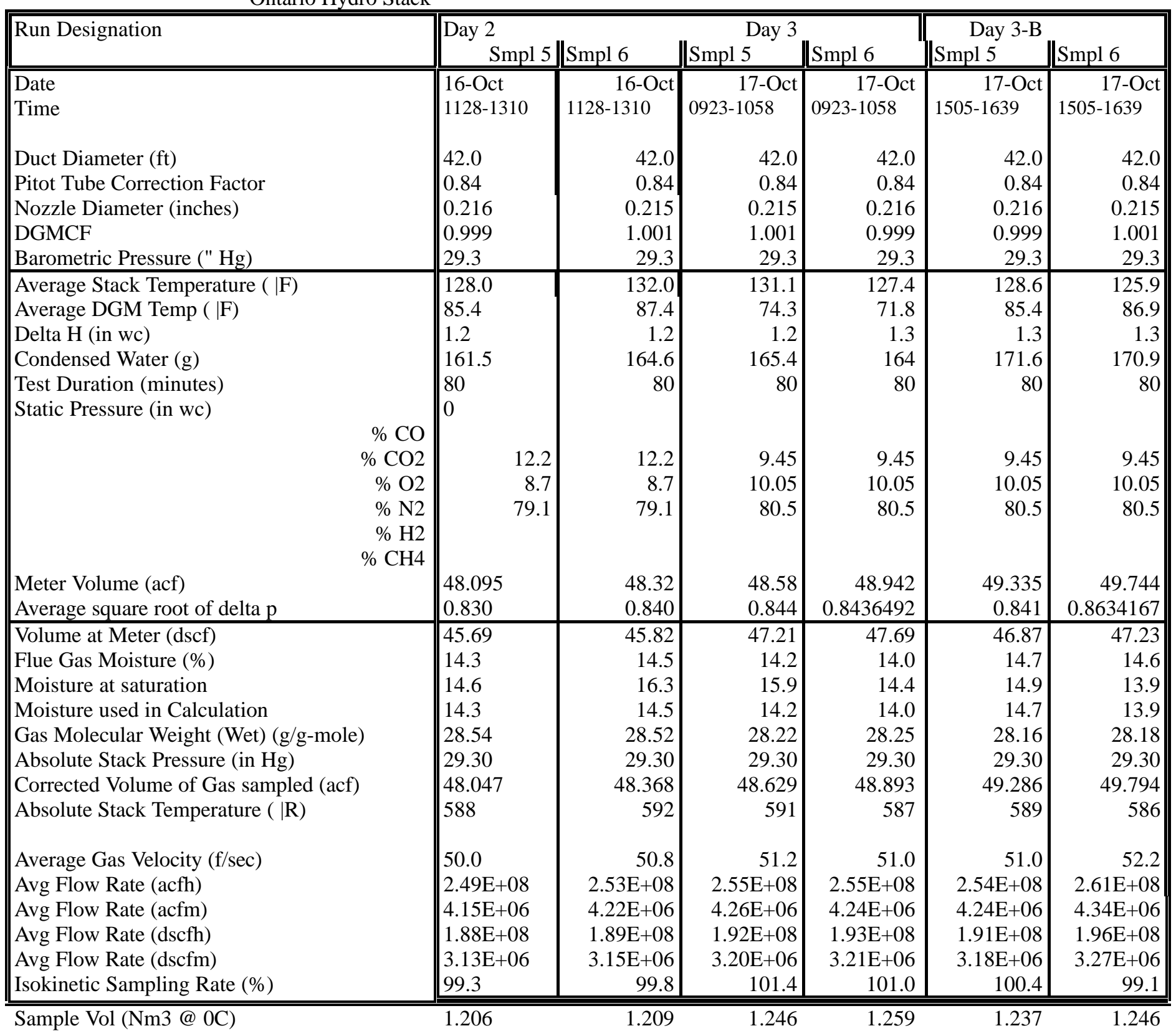


Ontario Hydro Quad Trains - Inlet

\begin{tabular}{|c|c|c|c|c|c|c|c|c|c|c|c|c|c|c|c|c|c|c|c|c|}
\hline \multirow{2}{*}{ Run Designation } & \multicolumn{4}{|c|}{ Day 1} & \multicolumn{4}{|c|}{$\overline{\text { Day } 2}$} & \multicolumn{4}{|c|}{ Day 3} & \multicolumn{4}{|c|}{ Day 4 - Run A } & \multicolumn{4}{|c|}{ Day 4 - Run B } \\
\hline & $\operatorname{Trn} 1$ & $\begin{array}{l}\text { Train } 2 \\
\end{array}$ & Train 3 & Train 4 & $\operatorname{Trn} 1$ & Train 2 & \begin{tabular}{|l|} 
Train 3 \\
\end{tabular} & Train 4 & $\operatorname{Trn} 1$ & Train 2 & Train 3 & Train 4 & $\operatorname{Trn} 1$ & Train 2 & Train 3 & Train 4 & Trn 1 & Train 2 & \begin{tabular}{|l} 
Train 3 \\
\end{tabular} & Train 4 \\
\hline \multirow{2}{*}{$\begin{array}{l}\text { Date } \\
\text { Time }\end{array}$} & 15-Oct & 15-Oct & 15-Oct & 15-Oct & 16-Oct & 16-Oct & 16-Oct & 16-Oct & 17-Oct & 17-Oct & 17-Oct & 17-Oct & 18-Oct & 18-Oct & 18-Oct & 18-Oct & 18-Oct & 18-Oct & 18-Oct & 18-Oct \\
\hline & 1309-1409 & \begin{tabular}{|l|l|}
$1309-1409$ \\
\end{tabular} & $\begin{array}{l}1309- \\
1409 \\
\end{array}$ & |1309-1409 & $1315-1415$ & $\begin{array}{l}1315- \\
1415 \\
\end{array}$ & $\begin{array}{l}1315- \\
1415 \\
\end{array}$ & $1315-1415$ & \begin{tabular}{|l|}
$1230-1330$ \\
\end{tabular} & $1230-1330$ & $1230-1330$ & $1230-1330$ & 0917-1017 & 0917-1017 & 0917-1017 & 0917-1017 & 1206-1306 & 1206-1306 & $1206-1306$ & $1206-1306$ \\
\hline \multirow{5}{*}{$\begin{array}{l}\text { Duct Diameter (ft) } \\
\text { Pitot Tube Correction Factor } \\
\text { Nozzle Diameter (inches) } \\
\text { DGMCF } \\
\text { Barometric Pressure (" } \mathrm{Hg} \text { ) } \\
\end{array}$} & 45.1 & 45.1 & 45.1 & 45.1 & 45.1 & 45.1 & 45.1 & 45.1 & 45.1 & 45.1 & 45.1 & 45.1 & 45.1 & 45.1 & 45.1 & 45.1 & 45.1 & 45.1 & 45.1 & 45.1 \\
\hline & 0.84 & 0.84 & 0.84 & 0.84 & 0.84 & 0.84 & 0.84 & 0.84 & 0.84 & 0.84 & 0.84 & 0.84 & 0.84 & 0.84 & 0.84 & 0.84 & 0.84 & 0.84 & 0.84 & 0.84 \\
\hline & 0.207 & 0.203 & 0.213 & 0.203 & 0.220 & 0.220 & 0.220 & 0.220 & 0.220 & 0.220 & 0.220 & 0.220 & 0.220 & 0.220 & 0.220 & 0.220 & 0.220 & 0.220 & 0.220 & 0.220 \\
\hline & 1.012 & 0.991 & 1.002 & 0.993 & 1.012 & 0.991 & 1.002 & 0.993 & 1.012 & 0.991 & 1.002 & 0.993 & 1.012 & 0.991 & 1.002 & 0.993 & 1.012 & 0.991 & 1.002 & 0.993 \\
\hline & 29.65 & 29.65 & 29.65 & 29.65 & 29.65 & 29.65 & 29.65 & 29.65 & 29.65 & 29.65 & 29.65 & 29.65 & 29.65 & 29.65 & 29.65 & 29.65 & 29.65 & 29.65 & 29.65 & 29.65 \\
\hline \multirow{6}{*}{$\begin{array}{l}\text { Average Stack Temperature ( || } \\
\text { Average DGM Temp ( |F) } \\
\text { Delta H (in wc) } \\
\text { Condensed Water (g) } \\
\text { Test Duration (minutes) } \\
\text { Static Pressure (in wc) }\end{array}$} & 340 & 340 & 340 & 340 & 347 & 347 & 347 & 347 & 348.5 & 348.5 & 348.5 & 348.5 & 342.5 & 342.5 & 342.5 & 342.5 & 346.2 & 346.2 & 346.2 & 346.2 \\
\hline & 88.5 & 88.2 & 87 & 84.3 & 99.4 & 96.3 & 99 & 99.2 & 96.8 & 92.9 & 91.3 & 90.7 & 85.1 & 81.6 & 80.5 & 78.3 & 87.2 & 85.4 & 84.0 & 82.0 \\
\hline & 0.97 & 0.9 & 1.1 & 0.9 & 1.16 & 1.16 & 1.2 & 1.20 & 1.2 & 1.2 & 1.2 & 1.2 & 1.2 & 1.2 & 1.1 & 1.1 & 1.2 & 1.2 & 1.2 & 1.1 \\
\hline & 62.0 & 59 & 68 & 52 & 62.3 & 62.8 & 62.3 & 67.4 & 68.1 & 66.9 & 64.3 & 66.4 & 68.7 & 69.5 & 60.8 & 70.9 & 77.6 & 74.7 & 77.9 & 77.6 \\
\hline & 60 & 60 & 60 & 60 & 60 & 60 & 60 & 60 & 60.0 & 60.0 & 60.0 & 60.0 & 60.0 & 60.0 & 60.0 & 60.0 & 60.0 & 60.0 & 60.0 & 60.0 \\
\hline & -23 & -23 & -23 & -23 & -23 & -23 & -23 & -23 & -23 & -23 & -23 & -23 & -23 & -23 & -23 & -23 & -23 & -23 & -23 & -23 \\
\hline \multirow{8}{*}{$\begin{array}{r}\% \mathrm{CO} \\
\% \mathrm{CO} 2 \\
\% \mathrm{O} 2 \\
\% \mathrm{~N} 2 \\
\% \mathrm{H} 2 \\
\% \mathrm{CH} 4\end{array}$} & & & & & & & & & & & & & & & & & & & & \\
\hline & 11.65 & 11.65 & $\begin{array}{l}11.65 \\
7.75\end{array}$ & $\begin{array}{l}11.65 \\
7.75\end{array}$ & $\begin{array}{l}11.65 \\
775\end{array}$ & $\frac{11.65}{775}$ & $\frac{11.65}{775}$ & $\frac{11.65}{775}$ & $\frac{11.65}{775}$ & $\frac{11.65}{7.75}$ & $\begin{array}{l}11.65 \\
7.75\end{array}$ & $\frac{11.65}{775}$ & $\frac{11.65}{7.75}$ & $\frac{11.65}{7.75}$ & $\frac{11.65}{7.75}$ & $\frac{11.65}{7.75}$ & $\frac{11.65}{7.75}$ & $\frac{11.65}{7.75}$ & $\frac{11.65}{775}$ & $\frac{11.65}{7.75}$ \\
\hline & 7.75 & 7.75 & 7.75 & 7.75 & 7.75 & 7.75 & 7.75 & 7.75 & 7.75 & 7.75 & 7.75 & 7.75 & 7.75 & 7.75 & 7.75 & $\begin{array}{l}7.75 \\
.07\end{array}$ & 7.75 & 7.75 & 7.75 & 7.75 \\
\hline & 80.6 & 80.6 & 80.6 & 80.6 & 80.6 & 80.6 & 80.6 & 80.6 & 80.6 & 80.6 & 80.6 & 80.6 & 80.6 & 80.6 & 80.6 & 80.6 & 80.6 & 80.6 & 80.6 & 80.6 \\
\hline & & & & & & & & & & & & & & & & & & & & \\
\hline & & & & & & & & & & & & & & & & & & & & \\
\hline & 31.926 & 32.017 & 33.151 & 31.05 & 34.668 & 36.751 & 35.691 & 37.642 & 37.183 & 37.236 & 35.154 & 36.359 & 34.132 & 36.006 & 33.915 & 34.761 & 35.194 & 36.011 & 35.358 & 36.011 \\
\hline & 0.8995 & 0.8995 & 0.8995 & 0.8995 & 0.885 & $\begin{array}{l}0.885 \\
\end{array}$ & 0.885 & 0.885 & 0.883 & 0.883 & 0.883 & 0.883 & 0.867 & 0.867 & 0.867 & 0.867 & 0.867 & 0.867 & 0.867 & 0.867 \\
\hline \multirow{8}{*}{$\begin{array}{l}\text { Dolume at Meter (dscf) } \\
\text { Flue Gas Moisture (\%) } \\
\text { Moisture at saturation } \\
\text { Moisture used in Calculation } \\
\text { Gas Molecular Weight (Wet) (g/g-mole) } \\
\text { Absolute Stack Pressure (in Hg) } \\
\text { Corrected Volume of Gas sampled (acf) } \\
\text { Absolute Stack Temperature ( |R) }\end{array}$} & 30.90 & 30.35 & 31.86 & 29.71 & 32.91 & 34.36 & 33.57 & 35.08 & 35.46 & 35.02 & 33.53 & 34.40 & 33.25 & 34.57 & 32.99 & 33.64 & 34.16 & 34.34 & 34.18 & 34.62 \\
\hline & 8.7 & $\begin{array}{l}8.4 \\
\end{array}$ & 9.2 & 7.6 & 8. & 7.9 & 8.1 & 8.3 & 8. & 8.3 & 8. & 8. & 8.9 & 8. & 8. & 9.0 & 9.7 & 9.3 & 9.7 & 9.6 \\
\hline & 837.2 & 837.2 & 837.2 & 837.2 & 916.3 & 916.3 & 916.3 & 916.3 & 934.0 & 934.0 & 934.0 & 934.0 & 864.8 & 86 & 864.8 & 864.8 & 906.6 & 906.6 & 906.6 & 906.6 \\
\hline & 8.7 & 8. & 9.2 & 7.6 & 8. & 7.9 & 8.1 & 83 & 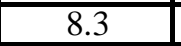 & 8. & 8. & 8. & 8. & 8 & 8 & 9.0 & 9.7 & 9.3 & 9.7 & 9.6 \\
\hline & 29.12 & 29.15 & 29.06 & 29.24 & 29.18 & 29.21 & 29.19 & 29.16 & 29. & 29.17 & 29.16 & 29.16 & 29.09 & 29.12 & 29.20 & 29.07 & 29.00 & 29.04 & 28.99 & 29.01 \\
\hline & 27.96 & 27.96 & 27.96 & 27.96 & 27.96 & 27.96 & 27.96 & 27.96 & 27.96 & 27.96 & 27.96 & 27.96 & 27.96 & 27.96 & 27.96 & 27.96 & 27.96 & 27.96 & 27.96 & 27.96 \\
\hline & 32.309 & 31.729 & 33.217 & 30.833 & 35.084 & 36.420 & 35.762 & 37.379 & 37.629 & 36.901 & 35.2 & 36.104 & 34.542 & 35.682 & 33.983 & 34.518 & 35.616 & 35.687 & 35.429 & 35.759 \\
\hline & 800 & 800 & 800 & 800 & 807 & 807 & 807 & 807 & 809 & 809 & 809 & 809 & 803 & 803 & 803 & 803 & 806 & 806 & 806 & 806 \\
\hline Average Gas Velocity (f/sec) & 64.0 & 64.0 & 64.1 & $\begin{array}{l}63.9 \\
\end{array}$ & 63.2 & 63.2 & 63.2 & 63.2 & 63.1 & 63.1 & & 63.1 & 61.8 & 61.8 & 61.7 & 61.9 & 62.1 & 62.0 & 62.1 & 62.1 \\
\hline \multirow{2}{*}{$\begin{array}{l}\text { Avg Flow Rate (acfh) } \\
\text { Avg Flow Rate (acfm) }\end{array}$} & $69 \mathrm{E}+08$ & $3.69 \mathrm{E}+08$ & $.69 \mathrm{E}+08$ & $3.68 \mathrm{E}+08$ & \begin{tabular}{|l|}
$3.64 \mathrm{E}+08$ \\
\end{tabular} & $3.64 \mathrm{E}+08$ & $3.64 \mathrm{E}+08$ & $3.64 \mathrm{E}+08$ & $3.64 \mathrm{E}+08$ & \begin{tabular}{|l|}
$3.64 \mathrm{E}+08$ \\
\end{tabular} & +08 & +08 & $3.56 \mathrm{E}+08$ & & $3.56 \mathrm{E}+08$ & +08 & $3.58 \mathrm{E}+08$ & $3.57 \mathrm{E}+08$ & $3.58 \mathrm{E}+08$ & $3.57 \mathrm{E}+08$ \\
\hline & $6.15 \mathrm{E}+06$ & $6.14 \mathrm{E}+06$ & $6.15 \mathrm{E}+06$ & $6.13 \mathrm{E}+06$ & $6.07 \mathrm{E}+06$ & $6.07 \mathrm{E}+06$ & & $6.07 \mathrm{E}+06$ & 106 & 6.0 & 06 & \begin{tabular}{|l|}
$6.06 \mathrm{E}+06$ \\
\end{tabular} & $5.94 \mathrm{E}+06$ & $5.93 \mathrm{E}+06$ & \begin{tabular}{|l|}
$5.93 \mathrm{E}+06$ \\
\end{tabular} & & $5.96 \mathrm{E}+06$ & \begin{tabular}{|l|}
$5.95 \mathrm{E}+06$ \\
\end{tabular} & \begin{tabular}{|l|}
$5.96 \mathrm{E}+06$ \\
\end{tabular} & $5.96 \mathrm{E}+06$ \\
\hline Avg Flow Rate (dscfh) & $2.08 \mathrm{E}+08$ & $2.08 \mathrm{E}+08$ & $2.07 \mathrm{E}+08$ & $2.10 \mathrm{E}+08$ & \begin{tabular}{|l|}
$2.04 \mathrm{E}+08$ \\
\end{tabular} & $2.05 \mathrm{E}+08$ & $2.05 \mathrm{E}+08$ & $2.04 \mathrm{E}+08$ & \begin{tabular}{|l|}
$2.03 \mathrm{E}+08$ \\
\end{tabular} & $2.03 \mathrm{E}+08$ & $2.03 \mathrm{E}+08$ & $2.03 \mathrm{E}+08$ & $2.00 \mathrm{E}+08$ & $2.00 \mathrm{E}+08$ & $2.01 \mathrm{E}+08$ & $1.99 \mathrm{E}+08$ & $1.98 \mathrm{E}+08$ & $1.98 \mathrm{E}+08$ & $1.98 \mathrm{E}+08$ & $1.98 \mathrm{E}+08$ \\
\hline \multirow{2}{*}{$\begin{array}{l}\text { Avg Flow Rate (dscfm) } \\
\text { Isokinetic Sampling Rate (\%) }\end{array}$} & $3.46 \mathrm{E}+06$ & $3.47 \mathrm{E}+06$ & $3.45 \mathrm{E}+06$ & $3.49 \mathrm{E}+06$ & \begin{tabular}{|l|}
$3.41 \mathrm{E}+06$ \\
\end{tabular} & $3.41 \mathrm{E}+06$ & $3.41 \mathrm{E}+06$ & $3.40 \mathrm{E}+06$ & \begin{tabular}{|l|}
$3.39 \mathrm{E}+06$ \\
\end{tabular} & $3.39 \mathrm{E}+06$ & $3.39 \mathrm{E}+06$ & $3.39 \mathrm{E}+06$ & \begin{tabular}{|l|}
$3.33 \mathrm{E}+06$ \\
\end{tabular} & $3.33 \mathrm{E}+06$ & $3.35 \mathrm{E}+06$ & $3.32 \mathrm{E}+06$ & $3.29 \mathrm{E}+06$ & $3.31 \mathrm{E}+06$ & $3.29 \mathrm{E}+06$ & $3.30 \mathrm{E}+06$ \\
\hline & \begin{tabular}{|l|}
101.8 \\
\end{tabular} & 103.7 & 99.5 & 100.8 & 97.6 & 101.6 & 99.4 & 104.1 & \begin{tabular}{|l|}
105.6 \\
\end{tabular} & 104.3 & 99.8 & 102.5 & 101.0 & 104.8 & 99.4 & 102.3 & 104.7 & 104.9 & 104.8 & 106.0 \\
\hline
\end{tabular}




\section{REQUEST FOR PATENT CLEARANCE FOR RELEASE OF CONTRACTED RESEARCH DOCUMENTS}

TO: For Technical Reports

AAD Document Control

MS F07

U.S. Department of Energy - FETC

PO Box 880

Morgantown, WV 26507-0880

Contract Agreement No.

DE-FC21-93MC30098

For Technical Reports

AAD Document Control

MS 921-143

U.S. Department of Energy - FETC

PO Box 10940

Pittsburgh, PA 15236-0940

Name \& Phone No. Of DOE COR

Thomas D. Brown, (412) 892-4691

For Technical Papers/Journal Articles/Presentations

Mark P. Dvorscak

U.S. Department of Energy

9800 South Cass Avenue

Argonne, IL 60439

FAX: (630) 252-2779

A. CONTRACTOR ACTION (CONTRACTOR COMPLETES PART A. 1-5)

1. Document Title: Field Validation of the Ontario Hydro Mercury Speciation Sampling Method at Site E-29; Fund 4426

2. Type of Document: Technical Progress Report Topical Report Final Technical Report

Abstract Technical Paper Journal Article Conference Presentation

Other (please specify):

3. Date clearance needed:

4. Patent information.

Yes No

Is any patentable subject matter disclosed in the report?

If so, has an invention disclosure been submitted to DOE Patent Counsel?

If yes, identify disclosure number or DOE Case Number

Are there any patent-related objections to the release of this report? If so, state the objections.

$\diamond$ 5. Signed

(Contractor)

Date July 6, 1999

Name \& Phone No. Sheryl E. Landis, Manager, Contracts and Intellectual Property (701) 777-5124

Address Energy \& Environmental Research Center, PO Box 9018, Grand Forks, ND 58202-9018

B. DOE PATENT COUNSEL ACTION

Patent clearance for release of the above-identified document is granted.

Other:

Signed

$$
\text { (Patent Attorney) }
$$

Date

- Must be completed by the contractor. 